Danmarks geologiske Undersøgelse.

II. Række. Nr. 51.

\title{
Lillebeltsler og London Clay
}

Af

Ellen Louise Mertz.

With an English Summary.

Kobenhavn.

C. A. Reitzel's Forlag.

1928.

Pris $3 \mathrm{Kr}$. 
Danmarks geologiske Undersøgelse.

II. Række. Nr. 51.

\section{Lillebeltsler og London Clay}

Af

Ellen Louise Mertz.

With an English Summary.

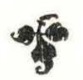

København.

C. A. Reitzel's Forlag.

1928. 
FR. BAGGES KGL. HOFBOGTRYKKERI 
Indholdsfortegnelse.

Indledning........... Side

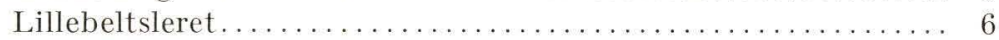

London Clay ............................. 10

Lerarternes fysiske Egenskaber .................... 13

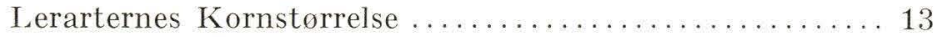

Lerarternes Hygroscopicitet ................. 17

Lerarternes naturlige Vandprocenter ............... 18

Lerarternes Konsistens ...................... 23

Lerarternes Konsistens ved kunstigt Vandindhold ... 24

Lerarternes Konsistensgræenser ............ 24

Lerarternes Konsistenskurver ........... 26

Lerarternes Konsistens ved deres naturlige Vandindhold 33

De æltede Prøvers Konsistens............... 33

De uæltede Provers Konsistens ............ 37

London Clay's 'og Lillebeltslerets Plads i den geologiske Tids-

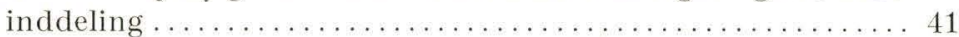

London Bassinets tertiære Dannelser..............44

Det ældre Tertiær i Danmark................. 43

Paleocænet.......................... 43

Eocænet........................... 44

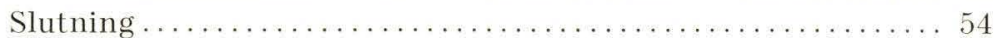

Summary of the Contents....................... 58 


\section{Indledning.}

T Aaret 1909 omtalte nu afdøde Professor N. V. Ussing i sin Artikel

i Tidsskriftet "Ingeniøren«: »Et Par Bemærkninger om Jordbundsforholdene paa Overfartsstederne ${ }^{1}$ ) Forholdene ved Lillebelt paa følgende Maade ${ }^{2}$ ): ». . . . . Helt anderledes er Jordbundsforholdene i Lillebælt. Dettes smalleste Del er en dybt nedskaaret Rende, der ikke alene gaar tværs gennem Istidsdannelserne, men endda et Stykke ned i disses Underlag; og det sidste er ikke Kridt eller Kalksten, men "plastisk Ler«. Hvad vi betegner med dette Navn, er en ensformig, overmaade fast, sandfri Lerart, absolut uigennemtrængelig for Vand, men i Modsætning til Morænemergelen tilbøjelig til langsomt at blødes op til en sej Vælling, hvor den ved Jordoverfladen er i stadig Berøring med Vand, hvorved voldes de bekendte Skred. I Konsistens (og for øvrigt ogsaa i Dannelsestid) svarer det plastiske Ler meget nær til det i Ingeniørkredse maaske bedre kendte London Clay .....

Denne sidste Bemærkning er det sikkert, der har foraarsaget den blandt Ingeniører gældende Anskuelse, at det plastiske Ler i Lillebelt, der i det følgende vil blive kaldt Lillebeltsler ${ }^{3}$ ), og London Clay er nøje sammenhørende, ikke alene i Alder, hvad jo har mindre Interesse for Teknikere, men ogsaa i Konsistens, d. v. s. i Kornstørrelse, i Henseende til Plasticitet, Vandsugningsevne o. s. v.

I Aaret 1923 blev Spørgsmaalet om Berettigelsen af denne Opfattelse pludselig aktuelt, thi medens der hidtil ikke havde været Brug for et nærmere Kendskab til Lillebeltslerets fysiske Egenskaber, blev det nu — takket være Vedtagelsen af Lovforslaget om en Bro over Lillebelt - af yderste Vigtighed at faa det bedst mulige Kendskab til Lerets Bæreevne, eftersom Boringerne i Lillebelt viste, at den paatænkte Bro for Strømpillernes Vedkommende skulde funderes i dette Ler.

Hertil anvendtes de geotekniske Undersøgelsesmethoder, der har til Formaal i videst mulig Udstrækning at lære en Lerarts fysiske Egenskaber at kende, og som først Aaret i Forvejen (i 1922) rent forsøgsmæssigt var blevet indført ved Danmarks geologiske Un-

\footnotetext{
1) „Ingeniøren «. 1909. S. 199.

2) 1. c. S. 200.

3) Se Begrundelsen af denne Betegnelse S. 50 .
} 
dersøgelse, hvorfor denne Institution af De Danske Statsbaner blev anmodet om at foretage Undersøgelsen af Prøverne. Imidlertid hefter der i disse de første Aar af de geotekniske Undersøgelsesmethoders Historie den Vanskelighed ved Bedømmelsen af Resultaterne, at man ikke faar et direkte Maal for den undersøgte Lerarts Bæreevne i dens naturlige Aflejring, thi Methodernes Arbejdsfelt er jo Laboratoriet og Materialet optagne og indsendte Boreprøver. De geotekniske Methoder egner sig derfor bedst til at give en relativ Bedømmelse af Lerarten, d. v. s. til at angive den enkelte Prøves Konsistens i Forhold til hele Lagets, eller dettes Konsistens i Forhold til et andet Lerlag, hvis Bæreevne er kendt gennem praktisk Erfaring.

For at faa et Maal for Lillebeltslerets Bæreevne gjaldt det derfor om at finde en Lerart, der var nær beslægtet med Lillebeltsleret i Henseende til fysiske Egenskaber, og hvis Værdi som Byggegrund var velkendt, og her faldt det da naturligt at have Opmærksomheden henvendt paa London Clay, der jo af Geologerne anses for at staa Lillebeltsleret nær saavel i Alder som i Konsistens, og som danner Undergrunden for mange af Londons største Byggearbejder. Den Opgave, der blev stillet Danmarks geologiske Undersøgelse af De Danske Statsbaner var da i Hovedlinierne følgende:

I. Hvorledes forholder de enkelte Prøver fra Prøveboringerne i Lillebelt sig til hele Laget (Gennemsnitsprøven)?

II. Er den i Professor Ussings Artikel i »Ingeniøren« fremsatte Opfattelse af Lillebeltslerets Konsistens stadig gældende?

III. Staar Lillebeltsleret og London Clay hinanden saa nær i Henseende til fysiske Egenskaber, at man tør overføre Erfaringer med Hensyn til sidstnævntes Bæreevne direkte til den danske Lerart?

Ovennævnte 3 Spørgsmaal suppleredes endvidere af Forfatteren med:

IV. Svarer Lillebeltsler og London Clay til hinanden i Alder.

Inden vi gaar over til at gennemgaa Resultaterne af de Undersøgelser, der danner Grundlaget for Besvarelsen af disse Spørgsmaal, skal der i det følgende gøres lidt nærmere Rede for det Prøvemateriale, der stod til Raadighed ved Undersøgelsen af de to Lerarter.

\section{Lillebeltsleret.}

Paa Danmarks geologiske Undersøgelses Lerlaboratorium er der ialt undersøgt 120 Prøver af det eocæne plastiske Ler fra Lillebelts 
Bund og Kystomraade. Disse Prøver er tillige med Prøverne fra de Lag, der overlejrer dem ved Beltets Kyster (se Profilet Tavle I) hovedsagelig udtaget langs to Borelinier: den vestlige og den østlige Brolinie. Medens samtlige Boringer, der er udført langs den førstnævnte Linie, blev foretaget i Sommeren 1923, falder de Boringer, der er udført langs den østlige Brolinie (den Linie, der tænkes benyttet til Byggearbejdet) i tre Afsnit, idet der første Gang boredes langs denne Linie i 1883 og derefter blev foretaget supplerende Boringer i $1923 \mathrm{og} 1926$.

Ved Borearbejderne i 1923 og 1926 blev der anvendt saavel Skylleboring som Tørboring, idet Skylleboret benyttedes til selve Boringen, medens Skrueboret anvendtes til Optagning af Prøverne. Ofte maatte der anvendes Mejsel til Gennemboring af de haarde Lag, men forøvigt skal der med Hensyn til de nærmere Detailler ved Boringerne henvises til den af Ingeniør ved De Danske Statsbaner, cand. polyt., S. Bransov i »Ingeniøren« publicerede Artikel ${ }^{1}$ ): "Forundersøgelser for Lillebæltsbroen«. Efter Optagningen blev Prøverne omhyggeligt befriet for den yderste Skal, der maatte formodes at have taget nogen Skade ved Arbejdet, og derefter blev hver Prøve for sig anbragt i et lukket, parafineret Glas og indsendt til Danmarks geologiske Undersøgelse.

Der var saaledes fra De Danske Statsbaners Side truffet de bedst mulige Foranstaltninger for at fremskaffe et godt Prøvemateriale, men een Ulempe havde man ikke kunnet overvinde: alle Prøverne havde — som Følge af Anvendelsen af Skruebor ved Arbejdet - faaet en Vridning, konform med Skruen; men bortset herfra var det et usædvanlig fint Prøvemateriale, der blev stillet til vor Raadighed til Undersøgelse af de gennemborede Lags fysiske Egenskaber, hvoraf dog kun Lillebeltslerets skal omtales i det følgende.

Undergrunden i samtlige Boreprofiler bestod, som tidligere nævnt, af det eocæne plastiske Ler, Lillebeltsleret, hvis Overflade blev truffet i følgende Dybder under Havfladen (se Profilerne Tavle I).

I. Vestlige Brolinie

(Boringerne anført efter Retningen Fyen-Jylland)

$\begin{array}{rccc}\begin{array}{c}\text { Boring } \\ \text { Nr: }\end{array} & \begin{array}{c}\text { Overfladens } \\ \text { Cote: }\end{array} & \begin{array}{c}\text { Lillebeltsleret } \\ \text { truffet ved }^{2} \text { ): }\end{array} & \begin{array}{c}\text { Boringen } \\ \text { ført ned til: }\end{array} \\ \text { XVI. } & +9,8 \mathrm{~m} & \div 16,3 \mathrm{~m} & \div 28,5 \mathrm{~m} \\ \text { II. } & \div 7,8- & \div 13,3- & \div 32,8- \\ \text { I. } & \div 14,2- & \div 14,2- & \div 34,2- \\ \text { III. } & \div 19,1- & \div 19,1- & \div 35,2-\end{array}$

1) „Ingeniøren«. 1925. Nr. 4.

${ }^{2}$ ) Den øverste Prove Lillebeltsler var dog starkt grus- og sandblandet paa de Punkter, hvor Lillebeltsleret dannede selve Bunden af Beltet. 


\begin{tabular}{|c|c|c|c|c|c|c|c|}
\hline & $\begin{array}{l}\text { Boring } \\
\text { Nr: }\end{array}$ & $\begin{array}{l}\text { Overfladen } \\
\text { Cote: }\end{array}$ & & $\begin{array}{l}\text { Lillebeltsler } \\
\text { truffet ved }\end{array}$ & & $\begin{array}{l}\text { Boringen } \\
\text { ført ned ti }\end{array}$ & \\
\hline & VIII. & $\div 26,8 \mathrm{r}$ & & $\div 26,8 \mathrm{r}$ & & $\div 46,8 \mathrm{r}$ & \\
\hline & VII. & $\div 39,3$ & - & $\div 39,3$ & - & $\div 49,3$ & \\
\hline & VI. & $\div 29,4$ & - & $\div 29,4$ & & $\div 51,7$ & \\
\hline & V. & $\div 14,1$ & - & $\div 18,6$ & - & $\div 30,4$ & \\
\hline & IV. & $\div 10,6$ & - & $\div 20,6$ & - & $\div 30,6$ & \\
\hline & $X V$. & $+5,0$ & - & $\div 23,5$ & - & $\div 32,5$ & - \\
\hline & (Boringen & $\begin{array}{c}\text { II. } \\
\text { anført e }\end{array}$ & $\begin{array}{l}\emptyset_{\mathrm{st}} \\
\text { efter }\end{array}$ & $\begin{array}{l}\text { lige Broli } \\
\text { Retningen }\end{array}$ & $\begin{array}{l}\text { ine } \\
: \text { F. }\end{array}$ & 1-Jyllan & \\
\hline & XVII. & $+\quad 6,8$ & $\mathrm{~m}$ & $\div 15,0$ & $\mathrm{~m}$ & $\div 27,2$ & $\mathrm{~m}$ \\
\hline & XVIII. & $+\quad 1,2$ & - & $\div 13,3$ & - & $\div 25,8$ & - \\
\hline & IX. & $\div 20,3$ & - & $\div 20,3$ & - & $\div 30,3$ & - \\
\hline Pille & 1. (Ø) & $\div 30,5$ & - & $\div 30,5$ & - & $\div 45,3$ & - \\
\hline- & 2. (Ø) & $\div 26,3$ & - & $\div 26,3$ & - & $\div 38,1$ & - \\
\hline - & $3 .(\varnothing)$ & $\div 26,5$ & - & $\div 26,5$ & - & $\div 41,5$ & - \\
\hline- & 4. (Ø) & $\div 20,9$ & - & $\div 20,9$ & - & $\div 35,0$ & - \\
\hline & XIII. & $\div 16,9$ & - & $\div 16,9$ & - & $\div 31,9$ & - \\
\hline & XII. & $\div \quad 9,6$ & - & $\div \quad 9,6$ & - & $\div 21,6$ & - \\
\hline & XIV. & $+6,7$ & - & $\div 15,1$ & - & $\div 30,3$ & - \\
\hline
\end{tabular}

Af ovenstaaende Tabel, samt af Profilerne Tavle I, der viser et Snit gennem Borelinierne, fremgaar det, at Lillebeltslerets Overflade har sin højeste Beliggenhed i Borehul XII, hvor det naar op til 9,6 m under Havfladen, samt at den dybest udtagne Prøve stammer fra Boring VI, hvor der er boret ned til $\div 51,7 \mathrm{~m}$; i samme Borehul boredes til den storste Dybde i Lillebeltsler nemlig ialt $22,3 \mathrm{~m}$.

Fælles for samtlige Boringer er endvidere den Omstændighed, at man i intet Tilfælde naaede at gennembore Lillebeltsleret, og at man derfor ikke ud fra de her udførte Boringer kan skønne om Lerets Mægtighed paa dette Sted. Selv om Lillebeltslerets Tilsynekomst i Klinterne langs Beltets Kyster tyder paa, at Laget efter sin Dannelse har været udsat for saa store Omvæltninger, at man skal være varsom med at slutte noget om dets Lejringsforhold, selv paa Grundlag af hinanden nærliggende Lokaliteter, saa vilde det heller ikke være at vente, at man skulde naa Lerets Undergrænse allerede ved den nævnte Cote $\div 51,7 \mathrm{~m}$, thi i nærliggende Boringer (Fredericia og Strib) har man boret henholdsvis c. $100 \mathrm{~m}$ og $70 \mathrm{~m}$ i Aflejringen, før man naaede dens Undergrænse, der laa i en Dybde af henholdsvis c. 113 m og c. 94 m under Overfladen.

Samtlige Prøver af Lillebeltsler viste en overordentlig fed, homogen Lerart, hvis Farve varierer fra mork-blaagraat til lysere graat med

1) se Note 2 paa forrige Side. 
brunlig Farvetone. Lerets oprindelige Farve er nemlig ikke bestandig overfor Dagslysets Indflydelse, idet den — selv hvor Leret ikke er udsat for direkte Sollys — har Tilbøjelighed til at »falme«, et Forhold, der har sin Aarsag i Lerprøvernes Indhold af Ferroforbindelser, der i Dagslyset iltes til Ferriforbindelser. Den saaledes omdannede Overflade danner dog kun en forholdsvis tynd Hinde over den oprindelige Lerprøve. Lerets Konsistens skal senere blive gjort til Genstand for nærmere Omtale; i denne Sammenhæng skal blot nævnes, at medens enkelte af Prøverne — selv i deres inderste Kærne — ved Sønderdeling viser klæbrige, ret ujævne »Brudflader«, opnaar man ved Sønderdeling af de fasteste Prøver i mange Tilfælde glatte, skinnende blanke Brudflader; sidstnævnte Egenskab ledsages altid af en dyb blaagraa Farvetone hos Leret.

Med Hensyn til Lillebeltslerets kemiske Sammensætning, da gav en Analyse af en Prøve fra Dagforekomsten i Røgle Klint, udført af Kemiker ved Danmarks geologiske Undersøgelse cand. polyt. Johs. Andersen, følgende Resultat:

\begin{tabular}{c|c|c|c|c|c|c|c|c|c|c|c}
\hline \hline $\mathrm{SiO}_{2}$ & $\mathrm{Al}_{2} \mathrm{O}_{3}$ & $\mathrm{Fe}_{2} \mathrm{O}_{3}$ & $\mathrm{TiO}_{2}$ & $\mathrm{MnO}$ & $\mathrm{CaO}$ & $\mathrm{MgO}$ & $\mathrm{K}_{2} \mathrm{O}$ & $\mathrm{Na}_{2} \mathrm{O}$ & $\mathrm{H}_{2} \mathrm{O}$ & $\mathrm{P}_{2} \mathrm{O}_{5}$ & $\mathrm{SO}_{3}$ \\
\hline 52,07 & 24,82 & 11,76 & 0,63 & 0,35 & 0,49 & 0,17 & 2,10 & 0,27 & 7,18 & $\mathrm{Sp}$. & $\mathrm{Sp}$.
\end{tabular}

Samtlige Lerprøver fra Boringerne afveg fra ovenstaaende Analyse ved at være i Besiddelse af et forholdsvis stort Indhold af Kalk, der dog, som det vil ses i det følgende, varierer ret stærkt, samt af en temmelig høj Vandprocent, der ligeledes vil blive nærmere omtalt i næste Afsnit.

Til ovenstaaende Bedømmelse af Lillebeltsleret, der udelukkende er baseret paa Prøvematerialet, kan knyttes et Par kortfattede Bemærkninger om Lerarten i Almindelighed, saaledes som den kendes fra Boringer og fra Dagforekomsterne ved Lillebelt og Refsnæs (se iøvrigt Beskrivelsen af Lillebeltsleret S. 45).

Lillebeltsleret er overalt, hvor man har truffet det, overordentlig fedt og ganske ensartet uden mindste Spor af indblandede Sandlag. Det udmærker sig ofte ved en stor Farverigdom, fra ildrødt til grønligt, gult eller graat. Mineralbestanddele er sjældne, saaledes er Indholdet af Glimmerblade yderst ringe. Af Forsteninger findes der kun ganske enkelte (disse vil senere blive omtalt i Afhandlingens geologiske Afsnit). Ved Undergrænsen af Laget og undtagelsesvis ogsaa i dettes nederste Del er ofte ved Boringer fundet Lag af vulkansk Aske.

Hvor Lillebeltsleret er udsat for Udtørring, dannes der ofte gabende Revner og Sprækker i den fede Lermasse, og ved senere Regnskyl bliver saadanne Lerklinter yderst tilbøjelige til at skride i stor Maalestok; disse Skredfænomener kan iagttages saavel paa Refsnæs som ved Lillebelts Kyster i Røgle- og Trælle Klinter. 


\section{London Clay.}

Da der fra De Danske Statsbaners Side var fremsat Ønske om at faa underkastet Prøver af London Clay den samme Undersøgelse som Lillebeltsleret for at sammenligne de to Lerarters fysiske Egenskaber, gjaldt det først og fremmest om at faa fremskaffet det bedst mulige Materiale af London Clay til Forsøgene. For at kunne danne sig et blot nogenlunde paalideligt Skøn om London Clay's Konsistens paa de Steder, hvor det med Held var anvendt som Byggegrund, var det nødvendigt at arbejde med Prøver, der var i Besiddelse af deres naturlige Vandprocent, og de Prøver af Lerarten, som Mineralogisk Museum elskværdigt stillede til vor Raadighed, opfyldte selvsagt ikke denne Fordring, hvorfor de ikke var fyldestgørende. Den samme Ulempe havde den Prøve London Clay, som Danmarks geologiske Undersøgelse velvilligst fik tilstillet fra »The Geological Survey of Great Britain«, thi ogsaa denne Prøve var en Museumsprøve, og bestod derfor af tørt Ler. Fra anden Side modtog De danske Statsbaner to store Prøver af London Clay, udtaget ved et Funderingsarbejde i England, men desværre var den ene Prøve for uren, den anden for utilstrækkeligt emballeret til at man ud fra dette Lers Vandprocent turde drage nogen Slutning angaaende London Clays Konsistens paa de Lokaliteter, hvorfra Prøverne var hentet. Alene den umiddelbare Betragtning af den bløde, klæbrige Lermasse, som disse Prøver bestod af, var nemlig tilstrækkelig til at overbevise os om, at disse Prøver ikke kunde være gode Repræsentanter for det London Clay, der af engelske Geologer betegnedes som "perfectly satisfactory« i Henseende til Værdi som Byggegrund $\left.^{1}\right)$. Den sidste Udvej til at faa fremskaffet et virkelig anvendeligt Materiale af London Clay blev da den: at udtage Prøverne paa Stedet specielt til det foreliggende Formaal og at drage Omsorg for, at Prøverne blev saa omhyggeligt emballerede, at deres Vandindhold ikke ændredes ved Forsendelsen. Takket være de Midler, der paa Initiativ af Direktør, Dr. phil. Victor Madsen, blev stillet til Raadighed for Sagen af henholdsvis »Skrikes Legat« og "Gammel KjøgegaardLegatet«, blev det muligt at gennemføre denne Plan, saaledes at en Repræsentant for De Danske Statsbaner, Ingeniør cand. polyt. S. Brannov, samt Forfatteren af denne Afhandling blev sat i Stand til at foretage Rejsen til London og personlig udtage Prøverne.

Disse Prøver af London Clay (ialt 9), der paa en Undtagelse nær er udtaget direkte af Byggegruben, har den Fordel fremfor Lillebeltsleret, at de ikke har været udsat for nogen Vridning under Udtagelsen, men er blevet skaaret ud af Byggegruben i store Terninger, og de frembyder

1) Udtrykket er benyttet i en Skrivelse fra »The Geological Survey of Great Britain» til Danmarks geologiske Undersøgelse. 
derfor et næsten ideelt Forsøgsmateriale. Efter Udtagelsen blev Prøverne straks anbragt i Blikdaaser, forsynet med tætsluttende Laag, der til yderligere Sikkerhed blev parafineret. Der kan saaledes ikke være nogen Tvivl om, at det Materiale af London Clay, som Dan marks geologiske Undersøgelse derved fik til Raadighed, var i Besiddelse af den naturlige Vandprocent paa de paagældende Lokaliteter. Disse var følgende:

Byggegruben, der benyttedes til Udvidelsen af Bank of England. Balham St., (Underground).

Picadilly Circus.

Waterloo St. (Underground).

Waterloo Bridge.

Daglokaliteten Sutton, hvor Prøven er udtaget i aabent Profil.

Desuden udtoges en Prøve af det plastiske Ler, der underlejrer London Clay, det saakaldte »Reading Bed«, der saavel i ejendommelig Farve som i Konsistens minder saa paafaldende om den røde Varietet af det danske Lillebeltsler, at en Prøve blev medtaget i Undersøgelsesrækken ${ }^{1}$ ).

Samtlige Prøver af London Clay viste fuldkommen Overensstemmelse med den almindelige Beskrivelse af Lerarten, saaledes som den findes i de engelske, geologiske Kortbladsbeskrivelser ${ }^{2}$ ), idet de bestod af ensartet, mørkegraat (ved Iltning brungraat) ret fedt Ler med blanke Brudflader.

I de engelske Beskrivelser af Lerarten findes desuden nævnt nogle Egenskaber, der ikke direkte lod sig paavise i de forholdsvis faa Prøver, der stod til vor Raadighed; saaledes omtaler f. Eks. Statsgeologen H. Dewey, at London Clay er rigt paa Septarier d. v. s. linseformede Kalkboller, saaledes som vi ogsaa kender dem fra vort danske oligocæne Septarieler ${ }^{3}$ ). Hist og her i Lerarten findes indlejret Sandlag, der er meget frygtede ved Funderingsarbejder, da Vandet fortrinsvis finder Vej gennem disse Lag, og derved fremkalder Svaghedspunkter i Leret. Hvor London Clay er udsat for Udblødning og derpaa følgende Udtørring, er det meget tilbøje-

1) Ved Udtagelsen af Proven af det stærktfarvede, plastiske Reading Bed-Ler kunde det ikke undgaas, at der medfulgte enkelte af de talrige Sandlag, der findes i denne Aflejring. Under Forsendelsen faldt det oprindelige hele Prøvelegeme i mange Stykker, og det var ikke muligt senere fuldstændigt at skille Sandet fra Leret. Bestemmelsen af Reading Bed-Lerets Kornstorrelse og Hygroscopicitet giver derfor ikke et fuldt paalideligt Billede af Lerarten.

Til Konsistensforsøgene var det ugørligt at faa en tilstrækkelig stor Prøve af blot nogenlunde rent Reading Bed-Ler, hvorfor disse Forsøg maatte opgives for denne Lerarts Vedkommende.

$\left.{ }^{2}\right)$ Se f. Eks.: Dewey, H. \& Bromenead, C. 1921: The Geology of South London. Mem. of the Geological Survey. England and Wales. Explanation of sheet 270. S. 33.

${ }^{3}$ ) De følgende Oplysninger om London Clay er elskværdigst meddelt Forf. af Statsgeolog ved "The Geological Survey of Great Britain", H. DEwey. 
ligt til at skride under paafølgende Regnskyl (sml. denne Bemærkning med Beskrivelsen af Lillebeltsleret S. 9); i høj Grad medvirkende til disse Skredkatastrofer er de omtalte Sandlag, idet Leroverfladen umiddelbart under disse Lag bliver stærkere udblødt end det øvrige Ler, og derved kommer til at virke som Glideflade for den overliggende Jordmasse.

I London Clay findes desuden en Del Forsteninger og Mineraler, som der senere skal kommes tilbage til i Afhandlingens geologiske Afsnit.

Som det fremgaar af ovennævnte Beskrivelse af Lerarterne falder den almindelige Opfattelse af Lillebeltsleret og London Clay sammen paa flere Punkter; der skal nu i det følgende ses, om denne Overensstemmelse kan staa for de mere objektive Undersøgelsesmethoder. 


\section{Lerarternes fysiske Egenskaber.}

\section{Lerarternes Kornstørrelse.}

Til Bestemmelsen af Lerarternes Kornstørrelse er anvendt den paa Danmarks geologiske Undersøgelses Laboratorium almindelig benyttede Fremgangsmaade ${ }^{1}$, altsaa en Kombination af Atterbergs og Schönes Slæmmemethoder.

I de senere Aar har imidlertid Statsgeolog ved Sveriges geologiska Undersökning, Stmon Johansson ${ }^{2}$ ) gjort opmærksom paa, at man ikke bør standse Slæmningen ved Grænsen $0,002 \mathrm{~mm}$, men yderligere adskille Korn under denne Størrelse i Grupperne 0,002-0,0006 mm $0,0006-0,0002 \mathrm{~mm} \mathrm{og}<0,0002 \mathrm{~mm}$, idet disse Grænser er meget vigtige, og de nævnte Grupper er derfor forsøgsvis medtaget i nedenfor angivne Slæmninger.

Ifølge Gunnar Ekströм³) knytter der sig følgende Egenskaber til de forskellige Kornstørrelsegrupper:

Kornstørrelse-Diameter:

2-0,2 mm (Sand): Denne Jordart lader Nedbøren passere uden at tilbageholde Fugtigheden i støre Grad (kun c. 5 Volumenprocenter). Kapillariteten er yderst ringe, og Sandet er derfor oftest, hvor det ikke hviler paa vandstandsende Lag, en tør Jordart.

0,2-0,02 $\mathrm{mm}$ (Mo): Jordarten har ikke plastiske Egenskaber, men den formaar at tilbageholde en Del af Nedbøren; den kapillære Stighøjde er ret stor, og Stigningen foregaar meget hastigt.

0,02—0,002 mm (Melsand): Ogsaa denne Kornstørrelsegruppe

1) Mertz, E. L. 1926: Metoder til Undersogelse af Lerets fysiske Egenskaber. D. G. U. II. R. 44 . S. $7-12$.

2) Johansson, Simon. 1913: Die Festigkeit der Bodenarten bei verschiedenem Wassergehalt. S. 42. Sveriges geologiska Undersöknings Årbok. Nr. 7.

3) Eкsтröм, G. 1926: Klassifikation av svenska åkerjordar. S. 19. Sveriges geologiska Undersöknings Årbok. Nr. 20. 


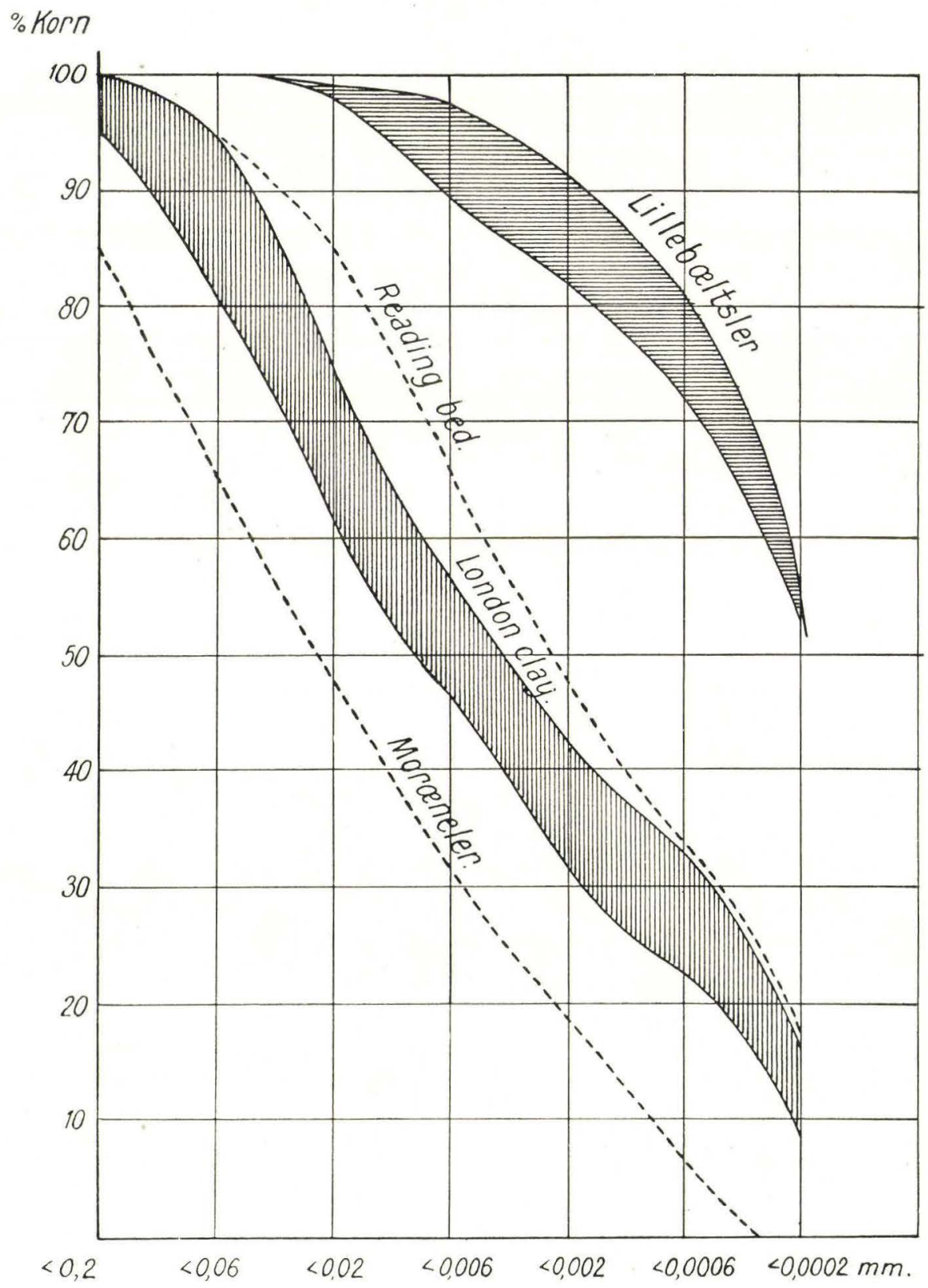

Fig. 1. Kurver over Kornstørrelserne for Lillebeltsler, Reading Bed (se Noten S. 11), London Clay og Moræneler fra Alssund. 
Tabel over Lerarternes Kornstørrelser.

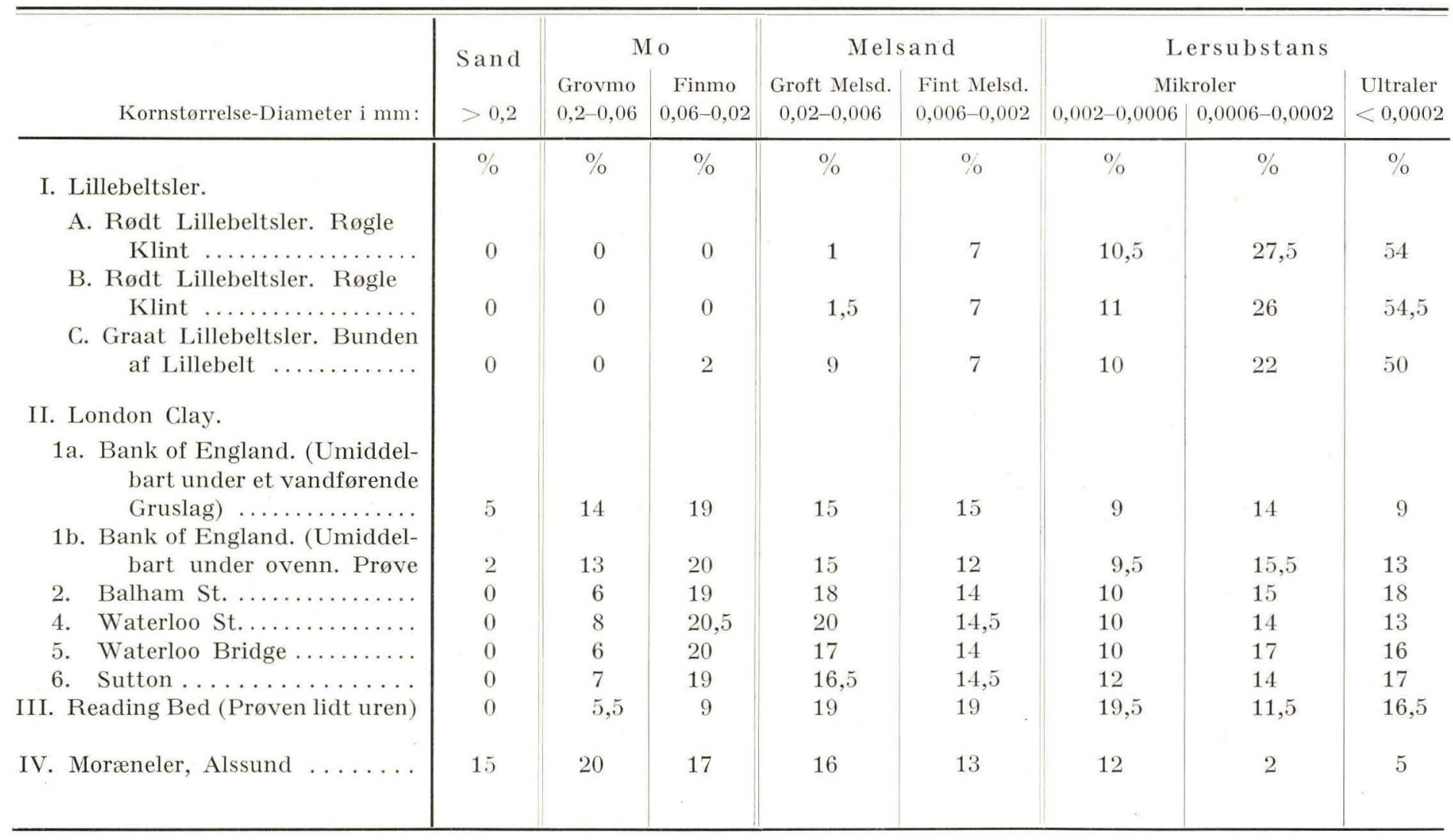


er uden Plasticitet og Betegnelsen: „Sand« er altsaa berettiget. I Melsandet synker Vandet yderst langsomt, og det formaar at tilbageholde relativt store Vandmængder.

$<0,002 \mathrm{~mm}$ (Lersubstans): Det er denne Kornstørrelse, der betinger den for Lerarterne karakteristiske Egenskab, Plasticiteten. I de senere Aar er det imidlertid blevet godtgjort, at to Lerarter, der begge har samme Procentdel af deres Masse liggende under $0,002 \mathrm{~mm}$, ingenlunde behøver at have samme fysiske Egenskaber, hvorfor Gruppen er inddelt som nævnt ovenfor i:

A. 0,002-0,0002 mm (Mikroler), der udskilles ved Benyttelsen af en Slæmmetid af 64 Døgn, hvis man benytter $30 \mathrm{~cm}$ Vædskesøjle, samt

B. $<0,0002 \mathrm{~mm}$ : (Ultraler), der findes ved at veje Slammet fra ovennævnte Slæmning.

Ifølge Srmon Johansson ${ }^{1}$ ) er endvidere Grænsen 0,0006 mm særlig vigtig, fordi Korn under denne Grænse modvirker Flydetendenserne hos Lerarterne, medens Korn mellem 0,06 og 0,0006 mm fremmer Flydningen, og Korn $>0,06 \mathrm{~mm}$ atter modvirker denne ${ }^{2}$ ). Grænsen, som fremkommer ved at indskyde Slæmmeintervallet 8 Døgn, er derfor medtaget ved Slæmningen af London Clay og Lillebeltsler.

Betragter man nu Kurverne S. 14 samt Skemaet S. 15, hvor der i begge Tilfælde er medtaget Resultatet af Slæmningen af Moræneler for at vise, hvor nær Lillebeltsleret og London Clay, trods indbyrdes Afvigelser dog staar hinanden sammenlignet med denne Lerart, vil man bemærke, at London Clay ganske vist er en fed Lerart, men at selv de fedeste af Prøverne (Balham og Sutton) dog bestaar af 25-26\% Mo, $32-31 \%$ Melsand og knapt c. $43 \%$ Lersubstans, medens den her foreliggende Prøve af Reading Bed ${ }^{3}$ ) har mindre Mo og mere Melsand end London Clay, men omtrent samme Lersubstans. Det danske Lillebeltsler bestaar derimod praktisk talt udelukkende af Lersubstans (c. $92 \%$ ), og

1) 1. c. p. $91-92$.

2) Disse Grænser lader sig imidlertid kun benytte i Praksis, naar der tages stærkt Hensyn til de lokale Forhold: Lagenes Hældning, de under- og overliggende Lag o. s. v., thi begunstiger disse Faktorer Flydetendenserne hos Leret, udvides Flydejords-Intervallet jo utvivlsomt. Forholdene ved den midtsjællandske Bane er et Eksempel herpaa. Jordarten, der fandtes i Dæmningen, var ganske vist en saakaldt "Lättlera" uden større Indhold af virkelig kolloidal Lersubstans, men nogen Flydejord efter svensk Definition var den ikke, idet c. $50 \%$ af Kornene tilhørte de Grupper, der modvirker Flydningen. Imidlertid laa Hovedparten af dette Materiale i Gruppen nærmest den nedre Flydegrænse (Gruppen: 0,1-0,06 mm), og da de lokale Forhold rimeligvis har bevirket, at ogsaa denne Kornstørrelse har fungeret som Flydejord, optraadte Lerarten i udpræget Grad som en saadan, idet den derved ialt kun raadede over c. $10 \%$ af virkelig modstandsdygtigt Materiale (Grus) til at hæmme Flydetendenserne hos Mo- og Finsandet.

3) Se Noten S. 11. 
da oven i Kobet over Halvdelen af hele Proven kommer ind under Betegnelsen Ultraler, staar den danske Lerart absolut i en extra Kornstørrelseklasse i Forhold til de andre Lerarter.

Det vilde imidlertid ikke være heldigt at bedømme de to Lerarters relative Finhed alene ud fra de her opnaaede Resultater, thi det kan ofte være overordentlig vanskeligt indenfor de fineste Kornstørrelsegrupper at bedømme, om Lerpartiklerne optræder i Enkeltstruktur, eller om de ved Kalk eller andre Bindemidler er kittede sammen til "uægte« Korn; saaledes maa f. Ex. det kalkholdige Lillebeltsler børstes i Timevis med svagt ammoniakholdigt Vand, før man tør være sikker paa, at alle Aggregaterne er udbørstede. Ved mine Undersøgelser er imidlertid ogsaa Prøverne af London Clay meget omhyggeligt udbørstede, og da Resultaterne af de øvrige Forsøg, saaledes som det vil fremgaa af de følgende Kapitler, peger i samme Retning som Resultatet af Slæmningen, er der ingen Grund til at betvivle, at den fundne Kornstørrelse for London Clay er magte«, og at Lillebeltsleret derfor er i Besiddelse af et over dobbelt saa stort Indhold af det for Lerets plastiske Egenskaber saa vigtige Ultraler, som London Clay.

\section{Lerarternes Hygroscopicitet.}

Ved en Lerarts Hygroscopicitet forstaar man den Vandprocent, udtrykt i Procent af Tørsubstans, som Lerarten indeholder, naar den har staaet til fuld Mætning i Vanddamp over 10\% Svovlsyre i Vacuum. Angaaende Laboratoriemethoden til Bestemmelsen af Hygroscopiciteten hos Leret henvises til den yderst grundige Gennemgang af Mitcherlichs Methode, dens Fordele og Ulemper, som findes i den tidligere citerede Afhandling af Gunnar Ekstrøm ${ }^{1}$ ). Her skal kun gives Resultaterne af Bestemmelsen af Hygroscopiciteten hos Lillebeltsler, London Clay og Reading Bed (samt Moræneler), saaledes som de er meddelt af Kemiker ved Danmarks geologiske Undersøgelse, cand. polyt. Johs. Andersen, der velvilligst har foretaget Bestemmelsen heraf efter ovennævnte Methode.

Hygroscopicitetstallet var for nævnte Lerarter følgende:

Lillebeltsler : $\left.21,4-21,6^{2}\right)$.

London Clay: 10,6.

(Reading $\left.\mathrm{Bed}^{3}\right)$ : 11,3).

(Moræneler : $4,0-4,5$ ).

1) 1. c. S. $87-100$.

${ }^{2}$ ) I en Prove fra Dagforekomsten af Lillebeltsler i Rogle Klint fandt Gunnar Екзтвӧм Hygroscopicitetstallet 23,8.

$\left.{ }^{3}\right)$ se Noten S. 11 . 
Det er den almindelige Antagelse, at Hygroscopicitetstallet giver et godt Maal for en Lerarts Finkornethed, i hvert Fald for dets Indhold af kollodialt Ler, en Opfattelse, der er paapeget saavel af GUNNAR Ekstrøm ${ }^{1}$ ) som her i Danmark af Harald Christensen ${ }^{2}$ ). Ifølge Undersøgelser, foretaget af førstnævnte kan man saaledes inddele de humusfri Lerarter i Henseende til Finkornethed efter Størrelsen af deres Hygroscopicitetstal i følgende Grupper:

»Lerfria Mineraljordar«........... Hygroscopicitetstal:

»Lätt Lera»...................

$<2$

»Lättere Mellanlera«...........

$2-4$

»Styvara do. $\ldots \ldots \ldots \ldots$.

$4-5,5$

$5,5-7$

"Styv Lera"..................

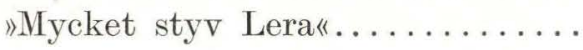

$7-10$

$>10$

Den største Hygroscopicitet, EкsтRøм overhovedet har naaet i en svensk Jordart, er 16-17.

Det fremgaar af ovenstaaende, at saavel Lillebeltsler som London Clay tilhører Gruppen de meget stive Lerarter, hvilket jo ogsaa stemmer med Resultaterne fra Slæmningen, men medens Lond on Clays Hygroscopicitetstal ligger ved den nedre Grænse for denne Gruppe, er der kun i et enkelt Tilfælde (i en Prøve fra Java ifølge Undersøgelser af Mitscherlich ${ }^{3}$ ) fundet en ligesaa høj Hygroscopicitet hos en Lerart, som den Lillebeltsleret har vist sig at være i Besiddelse af.

\section{Lerarternes naturlige Vandprocenter.}

Ved en Lerarts naturlige Vandprocent forstaas Middelvandprocenten for Leret i den paagældende Aflejring. Denne Vandprocent, der altsaa er afhængig saavel af Lerartens fysiske Egenskaber som af de rent lokale Lejringsforhold for Laget, har naturligvis kun Værdi, hvis de enkelte Prøvers Vandindhold ikke afviger for meget fra Middeltallet; ligeledes har Middelvandprocenten for Lerlag, der gaar frem i Dagen ingen særlig Betydning, idet en Række Bestemmelser af den, taget paa forskellige Tidspunkter, vil vise højst varierende Resultater og kun afspejle Svingninger i Nedbøren.

1) 1. c. S. $87-100$.

2) Christensen, Har. 1921: Om Nomenklaturen for og Klassifikationen af Jordarter og Jordbundsformer i de nordiske Lande. Nord. Jordbr. Forsk. Kjøbenhavn. Hft. 5-8.

3) Mrtscherlich, E. A., 1923: Bodenkunde für Land- und Forstwirte. Berlin. S. 73. 
I det foreliggende Tilfælde er imidlertid de nævnte Ulemper ikke til Stede. Med Hensyn til Lillebeltsleret, da er det overalt i den her omtalte Aflejring vanddækket og derfor ikke udsat for Vejrligets Indflydelse, og det vil da ogsaa fremgaa af omstaaende Tabel over Lerarternes Vandprocenter (i Tabellen er samtidig givet en Oversigt over deres Kalkprocenter), at Svingningerne i Vandindholdet indenfor Aflejringen ikke er store, og at man ikke engang, hvad man maaske paa Forhaand kunde have formodet, kan konstatere nogen Aftagen i Vandindholdet fra Overfladen af Laget og nedefter.

For London Clays Vedkommende stiller Forholdene sig noget anderledes, idet denne Lerart ikke er vanddækket paa de her omtalte Lokaliteter. Selv om man havde Ret til at antage, at Vandindholdet i de foreliggende Prøver, der alle med Undtagelse af Prøve 1a er udtaget adskillige Meter under Overfladen, i det mindste vilde give et Fingerpeg om det Vandindhold, London Clay har, naar det regnes for at danne en tilfredsstillende Byggegrund, maatte man derfor vente ret store Afvigelser fra Middeltallet, da Prøverne var udtaget i saa forskellig Dybde og paa Lokaliteter med ret stor indbyrdes Afstand. Resultaterne, der er angivet i omstaaende Tabel, viser imidlertid en glædelig Overraskelse i saa Henseende, thi Vandprocenten for London Clay, udtaget paa 5 forskellige Lokaliteter, viste sig at ligge indenfor saa snævre Grænser som $\left.18,8-23,8^{1}\right)$.

Vandprocenterne for Lillebeltsleret viser lidt større Afvigelser, men grupperer sig dog smukt omkring Middeltallet 31,9, med kun ganske faa større Udsving. Der skal endvidere gøres opmærksom paa, at samtlige større Afvigelser fra Middeltallet forekommer i 1ste Prøveserie, og de kan derfor muligvis i nogen Grad stamme fra manglende Erfaring med Hensyn til Prøvernes Behandling under Udtagelsen og Forsendelsen ${ }^{2}$ ).

Med Hensyn til de Boringer, der er foretaget paa de Punkter i Beltet, hvor Bropillerne for Lillebeltsbroen tænkes anbragt, og som vel derfor maa have størst Interesse, da fremgaar det af de Boreprøver (alle tilhørende 2 den Boreserie), der er stillet til vor Raadighed fra Borehullerne $\left.\mathrm{I} \varnothing, 2 \varnothing, 3 \varnothing \mathrm{og} 4 \emptyset^{3}\right)$, at Vandprocenten indenfor hver enkelt Borehul svinger overordentlig lidt, men at Prøverne fra Boringen $3 \varnothing$ og ogsaa tildels fra Boring $4 \varnothing$, begge beliggende paa Jyllandssiden, har et

1) Sidstnævnte Vandprocent fandtes i Prøve 1a, der var udtaget umiddelbart under et vandforende Gruslag.

$\left.{ }^{2}\right)$ Det er imidlertid hævet over enhver Tvivl, at de høje Vandprocenter i Boring XIII's Prøver ikke skyldes tilfældige Uheld, thi saavel for Ingeniør BRanvov, der ledede Prove-Optagningen, som for Forfatteren af denne Afhandling, der bearbejdede dem i Laboratoriet, stod det klart, at Prøverne fra dette Borehul ikke i Henseende til Fasthed stod paa Højde med det ovrige Boremateriale.

3) En anden Serie fra samme Boresteder, mrk. $1 \mathrm{~V}, 2 \mathrm{~V}, 3 \mathrm{~V}$ og $4 \mathrm{~V}$ blev straks efter Udtagningen indlemmet i De Danske Statsbaners Arkiv. 
noget større Vandindhold end Prøverne fra Boringerne $1 \varnothing$ og $2 \varnothing$ paa Fyensiden, idet Middeltallene for de 4 Borehuller var følgende:

$$
\begin{aligned}
& \text { Boring } 1 \varnothing \ldots \ldots \ldots \ldots . \ldots, 4 \% \text { Vand }
\end{aligned}
$$

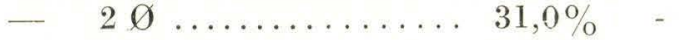

$$
\begin{aligned}
& \text { - } 3 \varnothing \ldots \ldots \ldots \ldots \ldots . \ldots \ldots, 1 \% \text { - } \\
& \text { - } 4 \varnothing \ldots \ldots \ldots \ldots \ldots 32,6 \% \text { - }
\end{aligned}
$$

Iøvrigt skal der senere under Kapitlet Lerarternes Konsistens gøres nærmere Rede for Følgerne af disse Svingninger indenfor Prøvernes Vandprocenter.

\section{De „naturlige Vandprocenter“og Kalkprocenter for Lillebeltsleret}

\begin{tabular}{|c|c|c|c|c|c|c|c|c|c|}
\hline Boring & Prove & $\begin{array}{c}\text { Cote } \\
\text { m }\end{array}$ & $\begin{array}{c}\text { Vand } \\
\% \\
\end{array}$ & $\begin{array}{c}\text { Kalk } \\
\% \\
\end{array}$ & Boring & Prove & $\begin{array}{c}\text { Cote } \\
\mathrm{m}\end{array}$ & $\begin{array}{c}\text { Vand } \\
\% \\
\end{array}$ & $\begin{array}{c}\text { Kalk } \\
\% \\
\end{array}$ \\
\hline \multirow[t]{5}{*}{ I } & 1 & $\div 14.2$ & 25.4 & 17.5 & & 42 & $\div 41.9$ & 30.6 & 6.8 \\
\hline & 2 & $\div 15.2$ & 30.2 & 28.5 & & 43 & $\div 46.8$ & 34.5 & 6.5 \\
\hline & 3 & $\div 20.1$ & 30.8 & 23.5 & IX & 44 & $\div 21.3$ & 37.6 & 13.5 \\
\hline & 4 & $\div 24.2$ & 26.9 & 8.3 & & 45 & $\div 25.6$ & 32.9 & 5.5 \\
\hline & 5 & $\div 34.2$ & 28.6 & 13.8 & & 46 & $\div 30.3$ & 29.7 & 10.3 \\
\hline \multirow[t]{5}{*}{ II } & 8 & $\div 13.8$ & 29.6 & 15.3 & $\mathrm{X}$ & 48 & $\div 16.3$ & 35.9 & 9.5 \\
\hline & 9 & $\div 16.9$ & 27.2 & 8.4 & & 49 & $\div 21.8$ & 39.7 & 12.5 \\
\hline & 10 & $\div 22.0$ & 32.0 & 12.5 & & 50 & $\div 25.8$ & 30.7 & 26.3 \\
\hline & 11 & $\div 27.2$ & 34.3 & 12.3 & & 51 & $\div 30.8$ & 32.3 & 17.8 \\
\hline & 12 & $\div 32.8$ & 34.5 & 14.1 & XI & 54 & $\div 16.0$ & 32.0 & 14.3 \\
\hline \multirow[t]{4}{*}{ III } & 13 & $\div 19.1$ & 37.7 & 14.5 & & 55 & $\div 21.0$ & 27.7 & 20.3 \\
\hline & 14 & $\div 25.8$ & 32.8 & 12.6 & & 56 & $\div 26.0$ & 33.6 & 16.8 \\
\hline & 15 & $\div 29.1$ & 31.6 & 18.0 & & 57 & $\div 31.0$ & 30.7 & 16.0 \\
\hline & 16 & $\div 35.2$ & 31.5 & 14.8 & XII & 58 & $\div 9.8$ & 37.0 & 25.8 \\
\hline \multirow[t]{4}{*}{ IV } & 22 & $\div 20.6$ & 34.5 & 11.8 & & 59 & $\div 12.1$ & 31.1 & 21.0 \\
\hline & 23 & $\div 21.1$ & 31.6 & 34.1 & & 60 & $\div 14.6$ & 33.0 & 8.3 \\
\hline & $24 \mathrm{~A}$ & $\div 26.1$ & 27.6 & 9.8 & & 61 & $\div 19.6$ & 34.3 & 15.3 \\
\hline & »B & $\div 30.6$ & 25.2 & 18.3 & & 62 & $\div 21.6$ & 32.7 & 10.3 \\
\hline \multirow[t]{3}{*}{$\mathrm{V}$} & 27 & $\div 19.1$ & 31.5 & 26.0 & XIII & 63 & $\div 17.9$ & 37.9 & 8.3 \\
\hline & 28 & $\div 25.1$ & 28.7 & 17.3 & & 64 & $\div 21.9$ & 42.2 & 9.5 \\
\hline & 29 & $\div 30.4$ & 29.0 & 13.8 & & 65 & $\div 26.9$ & 30.2 & 4.5 \\
\hline \multirow[t]{6}{*}{ VI } & 31 & $\div 29.4$ & 38.7 & 14.3 & & 66 & $\div 31.9$ & 31.1 & 7.3 \\
\hline & 32 & $\div 32.2$ & 32.9 & 14.1 & XIV & 74 & $\div 16.1$ & 28.3 & 20.3 \\
\hline & 33 & $\div 34.2$ & 30.1 & 13.3 & & 75 & $\div 20.3$ & 32.4 & 22.8 \\
\hline & 34 & $\div 38.2$ & 36.9 & 19.3 & & 76 & $\div 25.3$ & 29.5 & 13.5 \\
\hline & 35 & $\div 46.1$ & 32.1 & 7.5 & & 77 & $\div 30.3$ & 33.7 & 16.0 \\
\hline & 36 & $\div 51.7$ & 35.8 & 13.5 & XV & 88 & $\div 25.4$ & 30.4 & 20.3 \\
\hline VII & 38 & $\div 44.7$ & 28.4 & 18.5 & & 89 & $\div 30.0$ & 28.8 & 10.5 \\
\hline \multirow[t]{3}{*}{ VIII } & 39 & $\div 28.3$ & 29.6 & 17.5 & & 90 & $\div 32.5$ & 33.7 & 13.5 \\
\hline & 40 & $\div 31.6$ & 35.5 & 9.0 & XVI & 99 & $\div 18.2$ & 27.8 & 23.8 \\
\hline & 41 & $\div 36.5$ & 30.4 & 10.0 & & 100 & $\div 23.2$ & 28.3 & 18.3 \\
\hline
\end{tabular}

(bestemt af Kemiker ved Danmarks geologiske Undersøgelse, Ing. Johs. Andersen.) 


\begin{tabular}{|c|c|c|c|c|c|c|c|c|c|}
\hline Boring & Prove & $\begin{array}{c}\text { Cote } \\
\text { m }\end{array}$ & $\begin{array}{c}\text { Vand } \\
\%\end{array}$ & $\begin{array}{c}\text { Kalk } \\
\%\end{array}$ & Boring & Prove & $\begin{array}{c}\text { Cote } \\
\text { m }\end{array}$ & $\begin{array}{c}\text { Vand } \\
\%\end{array}$ & $\begin{array}{c}\text { Kalk } \\
\%\end{array}$ \\
\hline \multirow{4}{*}{ XVII } & 101 & $\div 28.5$ & 32.0 & 16.0 & \multirow{29}{*}{3 Ø. } & 10 & $\div 37.2$ & 29.9 & 1.5 \\
\hline & 108 & $\div 16.2$ & 26.2 & 40.0 & & 11 & $\div 38.1$ & 32.0 & 11.5 \\
\hline & 109 & $\div 21.2$ & 30.8 & 11.5 & & 3 & $\div 29.9$ & 34.1 & 2.5 \\
\hline & 110 & $\div 27.2$ & 33.6 & 12.5 & & 4 & $\div 30.6$ & 34.7 & 3.0 \\
\hline \multirow[t]{3}{*}{ XVIII } & 115 & $\div 13.8$ & 28.4 & 9.0 & & 5 & $\div 31.5$ & 33.0 & 3.0 \\
\hline & 116 & $\div 18.8$ & 30.2 & 18.3 & & 6 & $\div 32.3$ & 32.9 & 2.3 \\
\hline & 117 & $\div 25.8$ & 31.8 & 22.0 & & 7 & $\div 33.3$ & 33.5 & 2.3 \\
\hline \multirow{14}{*}{$1 \varnothing}$. & 2 & $\div 32.5$ & 31.2 & 15.8 & & 8 & $\div 33.8$ & 31.2 & 2.5 \\
\hline & 3 & $\div 33.6$ & 31.6 & 10.5 & & 9 & $\div 35.2$ & 35.3 & 6.3 \\
\hline & 4 & $\div 34.7$ & 32.9 & 14.0 & & 10 & $\div 36.4$ & 33.5 & 10.3 \\
\hline & 5 & $\div 35.9$ & 30.7 & 21.8 & & 11 & $\div 37.6$ & 32.2 & 10.3 \\
\hline & 6 & $\div 36.9$ & 30.0 & 35.0 & & 12 & $\div 38.8$ & 32.3 & 4.3 \\
\hline & 7 & $\div 37.9$ & 31.2 & 27.3 & & 13 & $\div 40.1$ & 32.4 & 7.3 \\
\hline & 8 & $\div 38.9$ & 30.5 & 31.0 & & 14 & $\div 41.5$ & 31.9 & 3.0 \\
\hline & 9 & $\div 39.8$ & 29.2 & 21.3 & & 2 & $\div 21.5$ & 33.3 & 15.3 \\
\hline & 10 & $\div 40.6$ & 29.8 & 18.5 & & 3 & $\div 22.5$ & 34.8 & 9.0 \\
\hline & 11 & $\div 41.6$ & 28.8 & 22.5 & & 4 & $\div 23.2$ & 33.4 & 8.0 \\
\hline & 12 & $\div 42.7$ & 30.8 & 5.0 & & 5 & $\div 24.1$ & 33.9 & 9.8 \\
\hline & 13 & $\div 44.0$ & 29.7 & 3.8 & & 6 & $\div 24.6$ & 31.0 & 10.5 \\
\hline & 14 & $\div 44.7$ & 29.1 & 8.0 & & 7 & $\div 25.0$ & 30.9 & 13.5 \\
\hline & 15 & $\div 45.3$ & 29.4 & 16.3 & & 8 & $\div 25.5$ & 33.7 & 16.5 \\
\hline \multirow{8}{*}{20.} & 2 & $\div 28.4$ & 31.8 & 13.5 & & 9 & $\div 26.4$ & 33.0 & 16.8 \\
\hline & 3 & $\div 29.7$ & 31.4 & 17.3 & & 10 & $\div 27.0$ & 33.2 & 14.3 \\
\hline & 4 & $\div 31.0$ & 30.3 & 18.5 & & 11 & $\div 27.2$ & 33.5 & 10.0 \\
\hline & 5 & $\div 32.0$ & 29.8 & 38.0 & & 12 & $\div 28.4$ & 33.7 & 11.3 \\
\hline & 6 & $\div 33.2$ & 31.3 & 12.0 & & 13 & $\div 29.2$ & 33.1 & 13.3 \\
\hline & 7 & $\div 34.2$ & 31.8 & 10.8 & & 14 & $\div 30.0$ & 32.3 & 10.3 \\
\hline & 8 & $\div 35.3$ & 30.9 & 13.5 & & 15 & $\div 31.0$ & 31.9 & 3.0 \\
\hline & 9 & $\div 36.2$ & 30.9 & 5.0 & & 16 & $\div 35.0$ & 27.6 & 17.5 \\
\hline
\end{tabular}

Middelvandprocenten for Lillebeltleret: 31.9

De „naturlige Vandprocenter“ og Kalkprocenter for London Clay.

\begin{tabular}{|c|c|c|c|c|c|c|c|}
\hline $\begin{array}{l}\text { Lokalitet } \\
\text { (se S. 12) }\end{array}$ & $\begin{array}{c}\text { Cote } \\
\text { m }\end{array}$ & $\begin{array}{c}\text { Vand } \\
\%\end{array}$ & $\begin{array}{c}\text { Kalk } \\
\%\end{array}$ & $\begin{array}{l}\text { Lokalitet } \\
\text { (se S. 12) }\end{array}$ & $\begin{array}{c}\text { Cote } \\
\text { m }\end{array}$ & $\begin{array}{c}\text { Vand } \\
\%\end{array}$ & $\begin{array}{c}\text { Kalk } \\
\%\end{array}$ \\
\hline $1 \mathrm{a}$ & - & 23.8 & 4.0 & & & & \\
\hline $1 \mathrm{~b}$ & - & 20.7 & 3.5 & 4 & - & 18.8 & 3.8 \\
\hline 2 & - & 22.5 & 4.5 & 5 & - & 20.1 & 3.6 \\
\hline 3 & - & 21.0 & 6.3 & 6 & - & - & 3.8 \\
\hline
\end{tabular}

Middelvandprocenten for London Clay: 21.1 
Hvad angaar Lillebeltslerets Indhold af Kalk, da vil man ved Betragtning af Tabellen hurtigt blive klar over, at det unddrager sig enhver Systematisering, idet Kalkprocenten svinger stærkt selv indenfor samme Boring. Maximum af Kalkindhold er fundet i Boring $2 \varnothing$ Pr. 5, hvor Procenten er 38,0, medens Minimum af Kalkindhold findes i Boring 2 Ø. Prøve 10, der kun indeholder 1,5\% Kalk.

Gennemgaaende kan man imidlertid sige om det her foreliggende Materiale af graat Lillebeltsler, at det i Modsætning til London Clays ret lave Kalkprocent har et ret stort Kalkindhold, hvilket betegner en Afvigelse fra den almindelige Regel, idet den graa Varietet af det danske eocæne plastiske Ler i Almindelighed anses for at være kalkfattigt eller endog kalkfrit $\left.{ }^{1}\right)$.

1) Se herom: Bøggild, O. B. 1918: Den vulkanske Aske i Moleret. D. G. U. II. R. 33. S. 113. 


\section{Lerarternes Konsistens.}

De i forrige Afsnit omtalte naturlige Vandprocenter hos Lerarterne paa de her behandlede Lokaliteter er selvsagt af afgørende Betydning, naar Talen er om at bedømme Lerarternes relative Værdi som Byggegrund, men uden særlig Interesse, naar man vil forsøge at sammenligne Lerarternes fysiske Egenskaber, thi den Vandprocent, en Lerart indstiller sig med i sin naturlige Aflejring er jo ikke alene et Resultat af den paagældende Lerarts fysiske Egenskaber, men afhænger ogsaa af de rent lokale Lejringsforhold paa Stedet. En Undersøgelse af Lerarternes forskellige Egenskaber maa derfor nødvendigt falde i to Afsnit:

I. En Paavisning af Forskellen i Lerarternes Konsistens (og hermed i deres fysiske Egenskaber), naar Lerarterne kunstigt bibringes samme Vandindhold.

II. En Paavisning af Forskellen i Lerarternes Konsistens, naar Lerarterne er i Besiddelse af hver sit Vandindhold, saaledes som de foreligger i deres naturlige Aflejringer.

Den første Undersøgelse (I.), der har Interesse, naar man ønsker at sammenligne een Lerarts fysiske Egenskaber med en andens (i Henseende til Finkornethed, plastiske Egenskaber o. 1. uafhængig af de lokale Lejringsforhold), foretages:

A. ved Bestemmelse af ATTERBERG's Konsistensgrænser hos Lerarterne (disse udtrykker de rent haandgribelige Tilstandsformer, Lerarterne gennemløber, naar de fra fuldkommen Tørhed, gradvis opnaar højere og højere Vandindhold).

B. ved at fastslaa Lerarternes Konsistenskurver ved Benyttelsen af det svenske, koniske Apparat (disse udtrykker den Modstand, Lerarterne yder mod en Kegles Nedsynkning, naar man - ligesom ved Bestemmelsen af Konsistensgrænserne - gradvis forhøjer deres Vandindhold).

Den anden Undersøgelse (II.), der har størst praktisk Betydning (ved Funderingsarbejder o. 1.), foretages ligeledes ved Benyttelse af det svenske, koniske Apparat, naar man ønsker at bedømme 
to Lerarters relative Fasthed i deres naturlige Aflejring, uanset om Lerarterne i Henseende til fysiske Egenskaber hører til samme Gruppe.

I de følgende Afsnit skal der gøres nærmere Rede for disse Undersøgelsesmethoder og Resultaterne af deres Anvendelse paa Lillebeltsleret og London Clay.

\section{Lerarternes Konsistens ved kunstige Vandindhold.}

\section{A. Lerarternes Konsistensgrænser}

(bestemt efter AтterberG's ${ }^{1}$ ) Methoder).

Ved en Lerarts Konsistensgræenser forstaas de Vandprocenter, ved hvilken Lerarten overgaar fra een Tilstandsform til en anden. Med stigende Vandprocenter gennemløber enhver Lerart følgende tre Hovedstadier:

$$
\begin{aligned}
& \text { Den faste Tilstandsform. } \\
& \text { Den plastiske Tilstandsform. } \\
& \text { Den flydende Tilstandsform. }
\end{aligned}
$$

Grænsen mellem den faste og den plastiske Tilstandsform (udtrykt i \% Vand af Tørsubstans) kảldes den nedre Plasticitetsgrænse, medens Grænsen mellem den plastiske og den flydende Tilstandsform kaldes den $ø$ vre Plasticitetsgrænse. Førstnævnte Grænse bestemtes af AtTerBERG, der først af alle har beskæftiget sig med Undersøgelsen af Lerets Konsistensgrænser, til at være lig den saakaldte Udrulningsgrænse, d. v. s. den Grænse, hvorved Leret bliver fugtigt nok til at lade sig udrulle til Traade; senere har Simon JoHAnsson ${ }^{2}$ ) flyttet den nedre Plasticitetsgrænse ned til Sammenpresningsgrænsen, d. v. s. den Vandprocent, hvorved Leret i det hele taget begynder at vise Tegn til Plasticitet, idet det lader sig sammenpresse til en samlet Klump. For at lette Muligheden for Sammenligning med ældre Forsøgsresultater, har jeg her benyttet Udrulningsgrænsen som nedre Plasticitetsgrænse, ogsaa fordi det forekommer mig, at den subjektive Fejlkilde, der jo er Ulempen ved alle Atterberg's Methoder, knapt spiller saa meget ind ved Bestemmelsen af Udrulningsgrænsen som ved Fastlæggelsen af Sammenpresningsgrænsen, hvor Grænsen bliver rykket længere ned, jo flere Fingerkræfter Geoteknikeren er i Besiddelse af. Den øvre Plasticitetsgrænse er der almindelig Enighed om at sætte ved Flydegrænsen o: den Vandprocent, ved hvilken Leret fra at være plastisk gaar over til at blive flydende. Den bestemmes som den Vandprocent, ved hvilken en Fure, ridset i en

1) Atterberg, A. 1911: Die Plastizität d. Tone. Int. Mitteil. f. Bodenkunde. Bd. I. S. 10 .

2) 1. c, S, 61 , 
Lerdejg, flyder til ved et Slag mod Skaalens Bund. Naturligvis er ogsaa denne Methode stærkt afhængig af Analytikeren, og jeg har derfor bedt den svenske Geotekniker, Gunnar Ekstrøm om at foretage Kontrolbestemmelser af Lerarternes Konsistensgrænser, idet disse da bedre kan sammenlignes med andre fra svensk Side publicerede Forsøgsresultater.

Dr. Ekstrøm's Bestemmelser, for hvilke jeg herved bringer ham min bedste Tak, ligger gennemgaaende lidt lavere end mine. De angives i den følgende Tabel, i hvilken til Sammenligning desuden er angivet Konsistensgrænserne (bestemt af Forf.) for en Prøve af Moræneler fra Alssund $\left.{ }^{1}\right)$ :

$$
\begin{array}{ccc}
\text { Den faste } & \text { Den plastiske } & \text { Den flydende } \\
\text { Tilstand } & \text { Tilstand } & \text { Tilstand }
\end{array}
$$

Lillebæltsler: $0-25,8 \%$ Vand $25,8-87,1 \%$ Vand over $87.1 \%$ Vand

London Clay: $0-19,8 \% \quad-\quad 19,8-56,8 \% \quad-\quad-56,8 \%$ -

Moræneler: $\quad 0-13 \% \quad-\quad 13-27 \% \quad-\quad-27 \% \quad-$

(fra Alssund)

NB. Samtlige Vandindhold er beregnet som \% af Tørstof.

Differencen mellem ATterberG's to Plasticitetsgrænser, Udrulningsgrænsen og Flydegrænsen, kaldes Plasticitetstallet; dette angiver saaledes det Antal Vandprocenter, ved hvilke Lerarten befinder sig indenfor det plastiske Omraade. Plasticitetstallet, der benyttes som et Maal for Lerarternes plastiske Egenskaber, er altsaa ifølge ovenstaaende Tabel følgende for de her omhandlede Lerarter:

Plasticitetstal:

Lillebeltsler ........ 61,3 Vandprocenter

London Clay. ........ $37,0 \quad$ -

Morænelersprøven...... 12,0 -

Medens Plasticitetstallet giver fuld Oplysning om det plastiske Omraades Størrelse, siger det intet om Plasticitetens Styrke indenfor Omraadet og heller intet om dette Omraades Beliggenhed paa Vandprocentskalaen; derved kan der forekomme det uheldige Tilfælde, at to Lerarter har samme Plasticitetstal uden at deres plastiske Omraade er sammenfaldende. Atтerberg ${ }^{2}$ ) har saaledes i sin Afhandling om disse Forhold hos Lerarterne nævnt to Lerarter, hvoraf den enes Plasticitetsgrænser var 30-57, den andens 40-67; de var altsaa højst forskelligt placeret paa Vandprocentskalaen, medens deres Plasticitetstal i begge Tilfælde var 27.

1) Den samme Prøve, der benyttedes til Sammenligning ved Slæmmeforsøgene.

2) 1. c. 1911 . S. 32 . 


\section{B. Lerarternes Konsistenskurver.}

(Resultatet af Undersøgelsen foretaget med det svenske, koniske Apparat, Fig. 2.)

Fremgangsmaaden ved Benyttelsen af dette Apparat, som findes beskrevet saavel i »Statens Järnvägars geotekniska Kommissions Slut. betänkande $\left.\ll^{1}\right)$, som i min tidligere Afhandling ${ }^{2}$ ) skal her kun gengives i ganske kortfattet Form:

Den Jordprøve, der ønskes undersøgt, æltes omhyggeligt, til den danner en fuldstændig homogen, svagt plastisk Masse (Sten, Konkretioner og lign. fjernes under Ailtningen. Saafremt Prøven ikke lader sig bearbejde ved sit naturlige Vandindhold, tilsættes lidt destilleret Vand. Derpaa fyldes Glasskaalen med Leret, saaledes at dettes Overflade staar glat og plan paa Højde med Skaalens Rand. Keglen, der vejer 60 gr og har en Spidsvinkel paa $60^{\circ}$, indstilles da saaledes, at dens Spids netop berører Lerets Overflade. Ved Hjælp af en Fjeder udløses Keglen derpaa af sin Hvilestilling, og den borer sig øjeblikkelig - paa Grund af sin Vægt - et Stykke ned i Leret. Nedsynkningen aflæses direkte paa Stilkens Inddelingsskala. Forsøget gentages $3-4$ Gange, og den endelige Bestemmelse af Nedsynkningen sker ved at tage Middeltallet af de aflæste Resultater. Hvis Prøven er tilstrækkelig godt æltet, beløber Afvigelserne fra Middeltallet sig sjældent til mere end 0,1-0,3 mm. Naar Keglens Nedsynkning i Leret er endelig fastslaaet, foretages en Bestemmelse af Lerets Vandprocent.

Dernæst æltes mere Vand ind i Lermassen, og Forsøget gentages; Keglen vil denne Gang synke lidt dybere, da Leret nu er blevet blødere; naar Nedsynkningen er fastslaaet, bestemmes det nye Vandindhold. Saaledes fortsættes Forsøget, idet man gentagne Gange ælter mere destilleret Vand ind i Lermassen, fra det Punkt, hvor Lerets Konsistens er paa Grænsen mellem stiv og plastisk, og videre gennem det plastiske Stadium til Skellet mellem dette og den flydende Tilstand. Der tages under Forsøget 4-5 Bestemmelser ved forskellige Vandindhold af Keglens Nedsynkning i Leret og af de tilsvarende Vandprocenter.

Afsætter man nu i et Koordinatsystem $60 \mathrm{gr-Keglens} \mathrm{Nedsynk-}$ ninger som Ordinater og de tilsvarende Vandprocenter som Abscisser, bliver Resultatet en Kurve, der angiver Lerets Modstand $\bmod 60$ gr $60^{\circ}$ Keglens Nedsynkning ved de forskellige Vandprocenter. Imidlertid har det vist sig, at denne Kurve ikke giver et fuldt tilfredsstillende Billede

1) Stockholm. 1922. S. 46.

2) Mertz, E. L. 1926: Methoder til Undersøgelse af Lerets fysiske Egenskaber. D. G. U. II. R, 44. S. 39. 
af Forsøgets Forløb, og man er derfor gaaet over til at lade Ordinaten udtrykke: Den Belastning, som man maa give Keglen for at tvinge den $10 \mathrm{~mm}$ ned i Leret, naar dette er i Besiddelse af den Vandprocent, som Abscissen angiver. Dette Tal lader

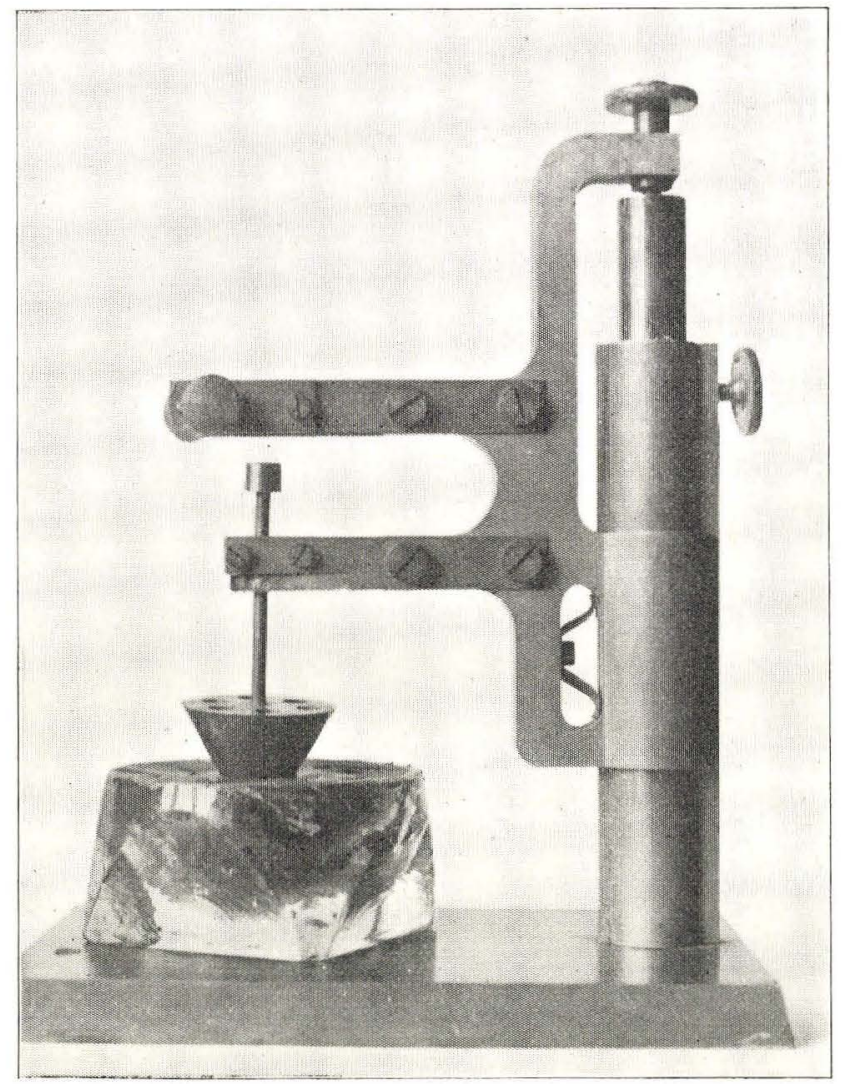

Fig. 2. Det koniske Apparat.

sig beregne af 60 gr Keglens Nedsynkning paa Grundlag af nogle i Sverige udarbejdede Tabeller.

Paa den grafiske Fremstilling S. 32 er indtegnet Konsistenskurverne for henholdsvis Lillebeltsler, London Clay og — til Sammenlignings-Grundlag - ogsaa Kurverne for det før omtalte Moræneler fra Bunden af Alssund.

Inden vi gaar over til at betragte de her nævnte Kurver, skal der dog først gøres lidt nærmere Rede for disses Betydning. Dette er saa meget mere paakrævet, som lignende Fremstillinger af Konsistenskurver publicerede saavel i min tidligere nævnte Afhandling over samme Emne ${ }^{1}$ )

1) 1 c. S. 48 . 
som i Ing. Brannov's ${ }^{1}$ ) Referat af Undersøgelserne af Lillebeltslerets fysiske Egenskaber, af og til er blevet mistydet, særligt af Teknikere, der har ment at kunne uddrage et Maal for Lerarternes Bæreevne af deres Kurvers Beliggenhed i Koordinatsystemet. Dette er ikke Tilfældet, og det kan ikke paapeges stærkt nok, at Konuskurverne alene kun giver et Maal for, hvor meget Vand en Lerart binder ved en bestemt Konsistens, altsaa et Maal for paagældende Lerarts

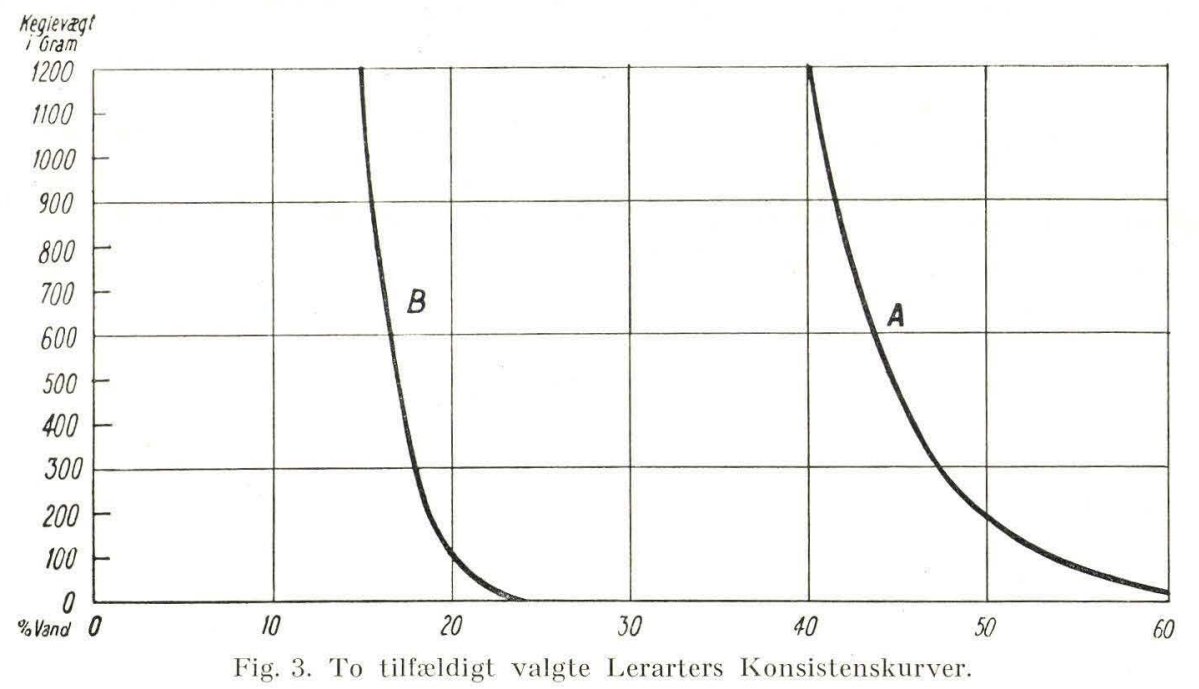

fysiske Egenskaber (først og fremmest for dens Finkornethed, idet en fed Lerart binder mere Vand end en mager). Har man f. Ex. to Lerarter A og B, hvis Kurver ligger som vist i Koordinatsystemet Fig. 3, saa kan man af disse Kurvers Beliggenhed — hvis det $\mathrm{i}$ begge Tilfælde drejer sig om humusfri Lerarter - kun faa oplyst, at A er mere finkornet end B, thi naar begge Lerarter har f. Ex. den Konsistens, hvorved 1200 gr Keglen synker $10 \mathrm{~mm}$ ned i Prøverne, indeholder A 40\%,.men B kun $15 \%$ Vand. Ud fra de to Kurvers Beliggenhed alene er der imidlertid ikke nogen som helst Mulighed for en Bedømmelse af de to Prøvers Værdi som Funderingsgrundlag, idet man maa gaa ud fra, at to forskellige Leraflejringer sjældent eller aldrig indstiller sig ved samme Vandindhold i Naturen. Det er saaledes nødvendigt, at man kender de to Lerarters naturlige Vandprocent-Omraade, før man indlader sig paa en Bedømmelse af deres relative Fasthed. (Hvis Prøve A i sin naturlige Aflejring indeholder netop 40\% Vand og Prøve B $15 \%$, er de to Jordarter jo f. Ex. lige modstandsdygtige overfor Keglens Nedsynkning).

i) »Ingeniøren «. 1925. Nr. 4. 
Desuden skal der gøres opmærksom paa, at Konsistenskurverne er tegnet paa Grundlag af æltede Prøvers Modstand mod Keglens Nedsynkning, og selv naar man kender de to Prøvers naturlige Vandprocenter, kan man ud fra disse Forsøg altsaa kun bedømme deres relative Fasthed ved disse i æltet Tilstand. Dette havde intet at sige, hvis de forskellige Lerarter svækkedes i samme Grad ved at blive æltet, men de senere Aars Forsøg paa dette Omraade har vist, at dette ingenlunde er Tilfældet, idet een Lerart svækkes f. Ex. til ${ }^{1 / 3}$, en anden maaske til ${ }^{1 / 10}$ af den oprindelige Bæreevne, naar Prøven æltes. Denne Opdagelse, der er gjort saavel af den svenske Geotekniker JoHn OLsson, som af Geologen ${ }^{1}$ ) Caldenius, bør for stedse slaa en Bom for Benyttelsen af Konsistenskurven som Grundlag for Vurderingen af forskellige Lerarters Fasthed. Undersøgelsen af Lerarternes Konsistens ved kunstigt tilsatte Vandindhold kan altsaa kun benyttes:

I. Til at genkende en Lerart fra den ene Lokalitet til den anden, det Konsistenskurven er yderst fintmærkende overfor Andringer i Lerets fysiske Sammensætning ${ }^{2}$ ). Derved opnaar man at kunne gøre Brug af de Erfaringer, man i Praksis har gjort med Hensyn til den paagældende Lerarts Egenskaber paa een Lokalitet og overføre dem til en anden; dog maa man naturligvis tage stærkt Hensyn til de forskellige lokale Forholds Indflydelse.

II. Til at paavise de enkelte Prøvers relative Fasthed indenfor s a m me Leraflejring, for hvilken Omsætningstallet fra æltet til uæltet Prøve vel maa være fælles, naar Leret iøvrigt er homogent. - Til dette Brug er Konsistenskurven i Forbindelse med den naturlige Vandprocent yderst velegnet, hvorfor den er blevet benyttet ved Undersøgelsen af Prøverne af Lillebeltsleret og senere ved Under-

1) Caldenius, C. C. 1925: Bidrag till kännedomen om relationen mellan markbeskaffenhet och markbärighet, sådan den registreras genom hălfasthetstalsbestämningar och bankbelastning. Ingeniors Vetenskaps Akademiens Handlingar Nr. 42. S. 15.

$\left.{ }^{2}\right)$ Man kunde maaske være tilbojelig til at tro, at naar Konsistenskurven hovedsagelig giver et Fingerpeg om Provens Finkornethed, vil den saa besværlige Slæmning af Lerarterne, der jo oftest tager Maaneder, kunne undvares. Dette er imidlertid ikke Tilfældet, thi medens Slæmmeresultatet giver et detailleret Billede af de enkelte Kornstorrelsegruppers Fordeling indenfor Lerarten, giver Konsistenskurven kun en Oplysning om det samlede Resultat af disse Gruppers Tilstedeværelse i Prøven. Ved udelukkende at holde sig til Konsistenskurven ved Bedommelsen af en Lerarts "Fedme" kan man desuden komme til et ganske misvisende Resultat. Dette vilde f. Ex. ske, hvis Leret indeholder humusholdige Bestanddele, thi selv en mager humusholdig Lerart kan binde mere Vand end en meget fed Lerart; ligeledes kan et stort Indhold af Glimmer virke misvisende paa Bedømmelsen, idet de bøjelige Glimmerblade giver Leret en mere plastisk Konsistens end et tilsvarende Indhold af andre Mineraler. Konsistenskurven giver blot et hurtigt, samlet Indtryk af Prøvens Finkornethed. I Stedet for at erstatte hinanden, supplerer de to Undersogelsesmethoder altsaa hinanden paa det bedste. 
søgelsen af Prøverne af London Clay for at vise den enkelte Prøves Afvigelse fra Middelprøven.

Efter at have fastslaaet Begrænsningen af Konsistenskurvernes Værdi vil vi gaa over til at betragte de Resultater, der er opnaaede ved at optegne Konsistenskurverne for de her omtalte Lerarter. Ved Bestemmelsen af Lillebeltslerets og London Clays Konsistenskurver kan man ganske se bort fra de Forstyrrelser et eventuelt Indhold af Humus-

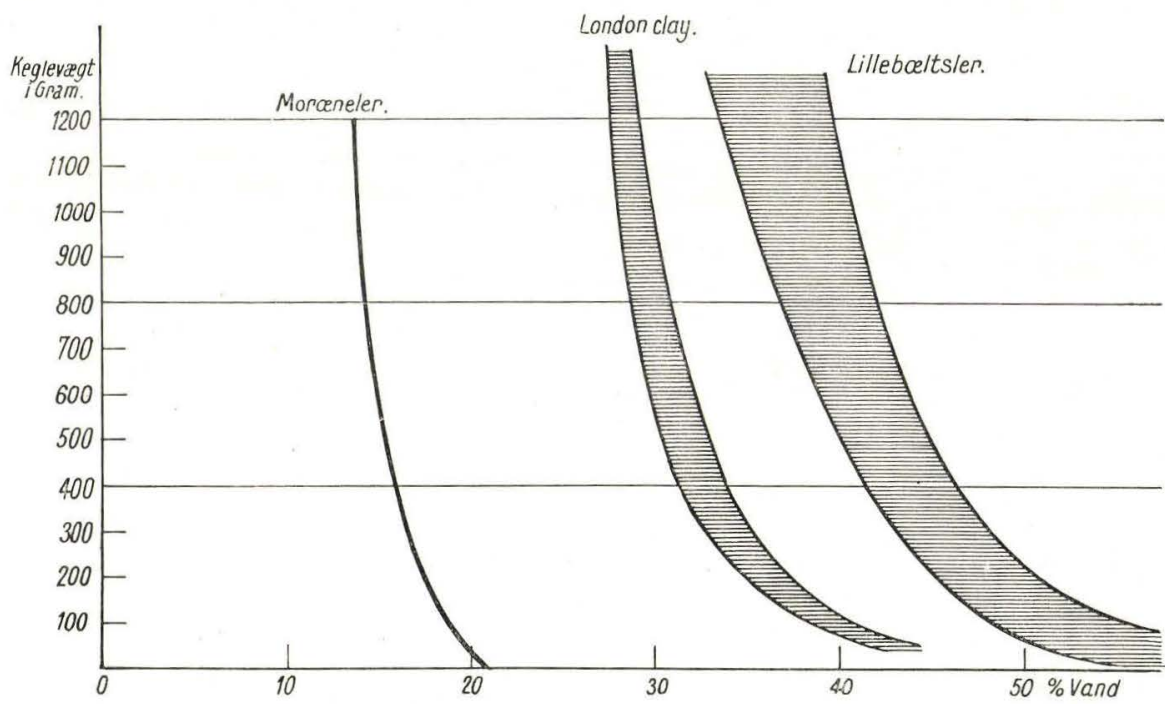

Fig. 4. Konsistenskurver for Lillebeltsler og London Clay samt Middelkurven for Moræneleret i Alssund.

Ved de to skraverede Felter er angivet Beliggenheden af samtlige Kurver for hver af de to forstnæunte Lerarter.

stoffer vilde bevirke, da begge Lerarter er fri for organiske Indblandinger. Da heller ikke Indholdet af de Mineraler, der betragtes som værende af Betydning for Plasticiteten (f. Ex. Glimmer), er til Stede i saa store Mængder, at de kan have nogen Indflydelse paa Lerarternes Konsistens, saa giver Kurverne for de her behandlede Lerarter udelukkende et Billede af disses Finkornethed og den deraf følgende Sammenhængskraft mellem Partiklerne ved de forskellige, kunstigt indarbejdede Vandindhold. Dette bekræftes ogsaa ved, at Kurverne for Lillebeltsleret - som det var at vente efter Slæmmeresultaterne - ligger en Del længere tilhøjre end Kurverne for London Clay, saaledes som det er vist paa Fig. 4, paa hvilken Ydergrænserne for det Omraade, indenfor hvilket samtlige Kurver for henholdsvis Lillebeltsleret og London Clay ligger, er angivet. Paa samme Figur er der desuden til Sammenligning indtegnet Middelkurven for Moræneleret fra Alssund. Det frem- 
gaar af denne grafiske Fremstilling, at Kurverne for hver af Lerprøverne grupperer sig ret tæt ved hverandre, og at der ikke er Tale om Overgribning mellem Kurvebundterne for de to Lerarter.

Vil man nu forsøge at efterspore de i forrige Kapitel omtalte Konsistensgrænser i Kurvernes Forløb, vil man se, at dette ikke er gørligt, indenfor det koniske Apparats Arbejdsfelt, da Kurverne ikke danner noget Knæ, der kunde angive en sikker Grænse mellem Tilstandsformerne, Det er derfor ikke muligt direkte at aflæse f. Ex. Flydegrænsens og Udrulningsgrænsens Plads paa den kontinuerlige, let svungne Kurveform, til Trods for, at de Vandprocenter ved hvilke disse Grænser er fundet at ligge (for Lillebeltsleret: henholdsvis 87, 1 og $25,8 \%$, for London Clay 56,8 og 19,8\% og for Morænelersprøven 27 og $13 \%$ af Tørsubstans) falder indenfor den her fundne Del af Konsistenskurverne (se Fig. 5 b, S. 32).

Imidlertid har Simon Johansson ${ }^{1}$ ) paavist, at Kurverne for Lerarternes Konsistens alle danner et Knæ ved Vandprocenter, der ligger under Ulrulningsgrænsen; men ved disse er Leret saa vanskeligt at ælte homogent, at der kræves særlige Apparater dertil. Nævnte Kurveknæ, der hverken ligger ved samme Abscisse eller samme Ordinat for de forskellige Lerarter, angiver netop Vandprocenten for Lerarternes Sammenpresningsgrænse, (se Omtalen af denne S. 24).

Flydegrænsen for de forskellige Lerarter er af GunNar Ekstrøm fundet at falde meget nær sammen med de Vandprocenter, der svarer til Kurvernes Ordinat 36,5 (Ordinat 219 efter dansk Beregningsmethode, se Fig. 5b, S. 32), hvilket altsaa vil sige, at Lerarterne ved Flydegrænsen er i Besiddelse af en konstant fælles Modstandsevne mod Keglens Nedsynkning.

Det vilde i høj Grad være ønskeligt ogsaa at kunne angive en Lerarts Konsistens ved et rent talmæssigt Udtryk, men her har der vist sig visse Vanskeligheder, da hverken Udrulningsgrænsen eller Flydegrænsen findes udtrykt i Kurveformen. Man har derfor indset Nødvendigheden af at erstatte de Atterbergske Konsistensgrænser og Plasticitetstal, hvis Bestemmelse jo ogsaa er behæftet med Muligheder for rent subjektive Fejl, med en mere objektiv Bedømmelse af Lerarternes Konsistens. Man kan f. Ex. gaa den Vej at udtrykke en Lerarts Konsistens ved dens Kurves Hældning, saaledes som de svenske Geoteknikere forlængst har indført det, idet de med deres Kurve-Karakter: "Vattenhaltsdifferencen« angiver Differencen mellem den Vandprocent (udtrykt i Procent af Tørstof), der svarer til »Hållfasthetstallet« 10 (60 gr Keglens 10 mm Nedsynkning), og den Vandprocent, der svarer til »Hållfasthets-

1) 1. c. 1914 . S. 68 . 


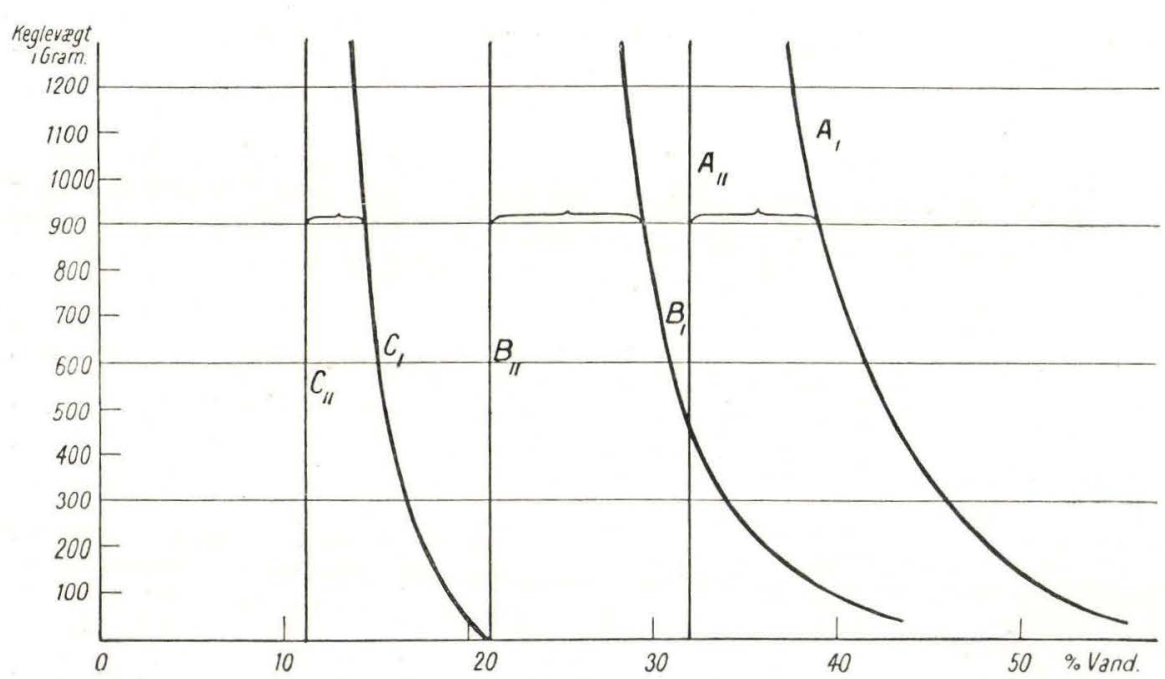

Fig. 5 a. Den i Danmark benyttede Form for Tegning al Konsistenskurver.

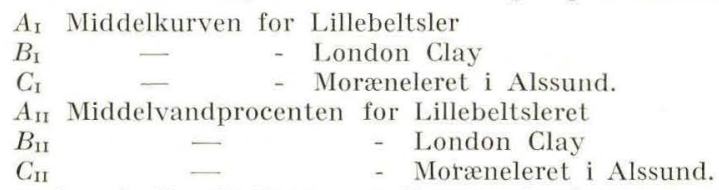

$\sim$ angiver hvilke Ordinater og Kurver, der hører sammen.

Vandprocenten angivet som $\%$ af Totalsubstans.

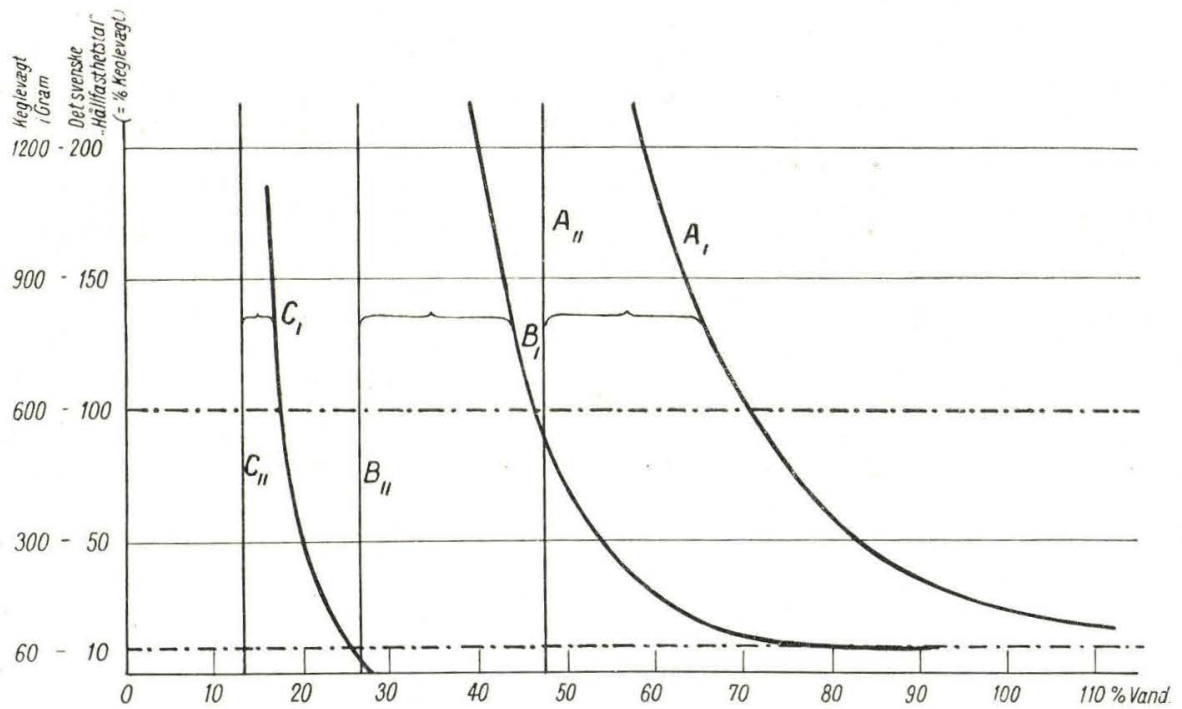

Fig. 5 b. Den i Sverige benyttede Form for Tegning af Konsistenskurver.

$A_{\mathrm{I}}, A_{\mathrm{II}}-B_{\mathrm{I}}, B_{\mathrm{II}}$ og $C_{\mathrm{I}}, C_{\mathrm{II}}$ samt $\sim$ har samme Betydning som paa Fig. 5 a, kun er Vandprocenten her beregnet som $\%$ af Tørstof; desuden angiver Tallene i Kolonnen nærmest Ordinataxen de svenske "Hăllfasthetstal , der for hvert af Kurvens Punkter udtrykker $1 / 6$ af den Keglevægt, som kræves til $10 \mathrm{~mm}$ Nedsynkning i Leret, naar dette har den ved Punktets Abscisse angivne Vandprocent. Differencen mellem Ordinaterne til de to Punkter, hvori de stiplede Linier skærer Kurven er $=$ den svenske Karakter: "Vattenhaltsdifferencen". 
tallet 100 (600 gr Keglens 10 mm Nedsynkning), en Karakter, der for de her undersøgte Lerarter, vilde blive: ${ }^{1}$ )

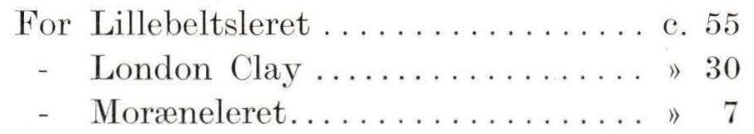

\section{Lerarternes Konsistens ved deres naturlige Vandindhold. \\ De æltede Prøvers Konsistens.}

Saavel AtTerberG's Konsistensgrænser som den svenske »Vattenhaltsdifferens", som er omtalt i foregaaende Kapitel, er beregnede paa Laboratorieforsøg med Benyttelsen af kunstigt tilsatte Vandprocenter i æltet Ler, og Kurverne alene siger derfor intetsombelst om de paagældende Lerarters Modstand mod ydre Paavirkning i deres naturlige Aflejring, idet der til Bestemmelsen af denne maa regnes med en anden meget vigtig Faktor, nemlig Lerarternes naturlige Vandprocent, en Faktor, der afhænger lige saa meget af paagældende Lerarters fysiske Egenskaber som af de rent lokale Aflejringsforhold.

Da den her behandlede Undersøgelse af Lillebeltslerets og London Clays fysiske Egenskaber havde det rent praktiske Formaal at vise, om man turde overføre Erfaringerne fra Funderingen paa London Clay direkte paa Beregningen af Lillebeltslerets Bæreevne, var det ganske utilstrækkeligt, at man gennem Slæmning og Konsistenskurver fik at vide, at Lillebeltsleret, fordi det er federe end London Clay, er fastere end dette, hvis de to Lerarter bibringes en og samme Vandprocent. Det, det kom an paa, var jo nemlig at faa oplyst Lerarternes Fasthed i deres naturlige Aflejringer, hvor man ikke paa Forhaand havde nogen som helst Ret til at forudsætte, at de skulde have samme Vandindhold. Paa det Tidspunkt, da Beretningen om Lillebeltslerets fysiske Egenskaber indgik fra Danmarks geologiske Undersøgelse til

1) Der foreligger ikke fra svensk Side nogen Angivelse af Grunden til, at netop disse to Punkter er valgt som Grundlag for Kurveberegningen, men Aarsagen maa vel soges i deres rent talmæssige Fordel. Det forekommer mig imidlertid, at man ved at vælge den til Ordinaten 100 svarende Abscisse, en Vandprocent, ved hvilken Leret befinder sig midt inde i det plastiske Omraade, benytter et for lille Afsnit af Kurven. Ved Hallfasthetstallet 200 (der jo svarer til det danske Ordinat 1200, se Fig. 5 b) f. Ex. bearbejder man endnu Leret med Lethed, og ved den tilsvarende Vandprocent er Leret kun lige naaet at blive plastisk. Man vilde derfor ved at benytte f. Ex. denne Ordinat som Udgangspunkt opnaa at faa Storsteparten af det plastiske Omraade indesluttet i "Vattenhaltsdifferencen «, og dette vilde da maaske blive mere folsomt overfor Nuancer indenfor Lerarterne. 
De Danske Statsbaner, havde vi imidlertid — som nævnt i Forordet - ingen Mulighed for at kende Vandprocenten for London Clay, hvorfor vi maatte afholde os fra en Bedømmelse af Lerarternes relative Fasthed i deres naturlige Aflejring, indtil et saadant Kendskab kunde opnaas. Takket være den tidligere nævnte Rejse til England, lykkedes det os imidlertid at faa det Kendskab til London Clays Vandindhold, der er angivet i Tabellen S. 21, hvorfor vi nu er i Stand til at foretage en Sammenligning mellem de to Lerarters Fasthed ved deres naturlige Vandindhold.

Paa den grafiske Fremstilling S. 32 er indtegnet samme Konsistenskurver som paa Fig. 4, S. 30; kun er paa Fig. 5 a og 5 b S. 32 ogsaa indtegnet de Ordinater, der angiver Middelvandprocenten for Lerarterne i de her omtalte Aflejringer. (Ved Tegningen af Kurverne Fig. 5 a er Vandprocenten beregnet som Procent af Totalsubstans, paa Fig. 5 b som Procent af Tørstof).

Disse Figurer, der altsaa giver et Billede af de æeltede Lerarters Middelkurver og Middelvandindhold, egner sig imidlertid ikke til Benyttelse for Teknikerne, der netop har Interesse i at kende de "unormale Punkter« i Leret og disses Afvigelse fra Middelprøven, en Afvigelse, der enten kan være betinget af en Andring i Kurveformen (Prøvens Finkornethed) eller i Ordinaten for den naturlige Vandprocent for paagældende Prøve. For at vise, hvor store Afvigelserne kan være, er der paa Fig. 6, S. 35 gengivet Kurven for

1) Den fedeste Lerprøve.

2) 》 magreste -

3) \ fasteste -

4) » blødeste -

af Lillebeltsleret.

Den rltede Prøves Fasthed afspejler sig i Konsistenskurvens Beliggenhed i Forhold til den naturlige Vandprocent. Er denne Afstand stor, vil Skæringspunktet mellem Vandprocentlinien og Kurven faa en stor Ordinat eller med andre Ord, Prøven vil ved sin naturlige Vandprocent yde stor Modstand mod Keglens Nedsynkning (se Ex. 3 Fig. 6). Er Afstanden mellem Kurve og Ordinat lille, skærer de to Linier hinanden muligvis allerede indenfor det her benyttede Apparats Arbejdsfelt, og den paagældende Prøve har da været saa blød, at den ved $\sin$ naturlige Vandprocent har kunnet æltes og har kun ydet forholdsvis ringe Modstand overfor Keglens Nedsynkning (se Ex. 4, Fig. 6). Af Figurerne fremgaar endvidere, at de fedeste Prøver (॰: de, der ligger længst t. h. i Koordinatet) ikke behøver at være de fasteste; det afhænger ganske af Prøvens naturlige Vandprocent.

For at faa et talmæssigt Udtryk for de forskellige Prøvers Fasthed i Forhold til Middelprøven, har Danmarks geologiske Undersøgelse 
efter De Danske Statsbaners Ønske defineret et saakaldt Konsistenstal, der angiver den Vægt, Keglen skal have for at trænge $10 \mathrm{~mm}$ ned i den æltede Lerprøve, naar denne er i Besiddelse af Prøvens naturlige Vandprocent, eller grafisk fremstillet: Kurvens Skæring med Ordinaten for den naturlige Vandprocent. Dette Tal (der intet siger om Lerets fysiske Egenskaber, idet

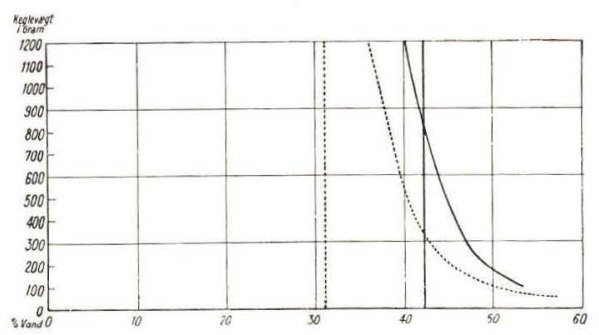

Exempel 1.

Den fedeste Prove af Lillebeltsleret. Prøvens Kurve ligger t. h. f. Middelkurven.

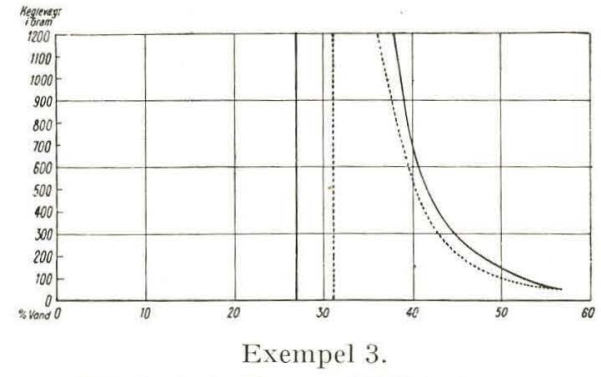

Den fasteste Prøve af Lillebeltsleret. Stor Afstand mellem Kurve og Vandprocent.

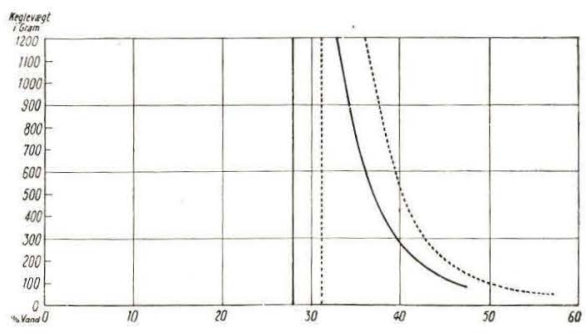

Exempel 2.

Den magreste Prove af Lillebeltsleret. Provens Kurve ligger t. v. f. Middelkurven.

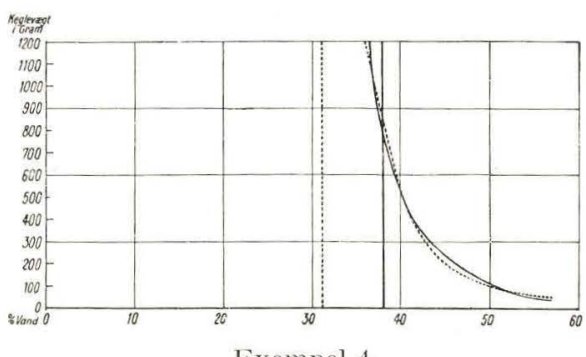

Exempel 4.

Den blødeste Prove af Lillebeltsleret. Lille Afstand mellem Kurve og Vandprocent.

Fig. 6.

De fuldt optrukne Kurver og Ordinater paa Figurerne angiver Konsistenskurver og Vandprocenter for paagældende Prover Lillebeltsler.

De punkterede Kurver og Ordinater viser til Sammenligning Middelkurver og Middelvandprocenten for Lerarten.

en fast, mager Prøve har et højt, en blød, fed Prøve et lavt Konsistenstal o. s. v.) er meget fordelagtigt at benytte, naar Talen drejer sig om Sammenligning mellem Prøver af samme Lerart, men det har sin Begrænsning, og man maa tage sig i Agt for ikke at overvurdere det; thi Konsistenstallet udtrykker jo kun den æltede Prøves Fasthed, og da, som tidligere nævnt, CaLdenius har vist, at de forskellige Lerarters Fasthed ændrer sig yderst forskelligt ved Altning, og det hidtil ikke er lykkedes at udfinde nogen Lovmæssighed heri, saa vil det forstaas, at en Sammenligning mellem f. Ex. en fed og en mager Lerarts Fasthed paa Grundlag af Konsistenstallet er ganske forkastelig ${ }^{1}$ ).

1) Naar der i den tidligere citerede Artikel af Sven Brannov i »Ingenioren (1925. Nr. 4) »Forundersøgelser for Lillebæltsbroen» omtales, at Lillebeltsleret har et Konsistens- 
Efter at have fastslaaet, at Konsistenstallet kun er anvendeligt ved Undersøgelser indenfor samme Lerlag, saaledes som det f. Eks. er benyttet til at fastslaa Nuancerne indenfor Lillebeltsleret, skal der nedenfor anføres de Betegnelser, der i Beretningen om Lillebeltslerets fysiske Egenskaber til De Danske Statsbaner blev knyttet til de forskellige Konsistenstal. Disse var følgende:

Prøver, hvis Konsistenstal laa under $1000 \quad$ kaldtes meget bløde

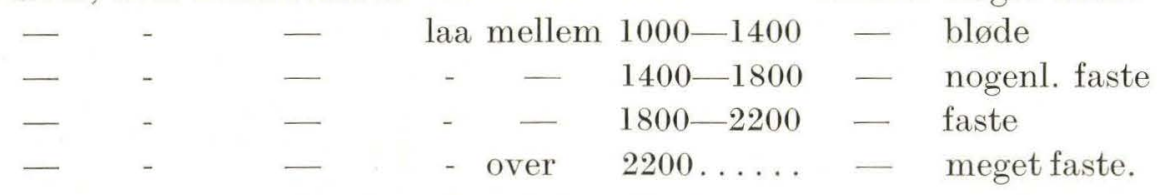

Disse Grænser er ikke tilfældigt valgt, selv om de gaar jævnt over i hinanden, thi en Prøve Lillebeltsler, hvori 1000 gr-Keglen kan synke $10 \mathrm{~mm}$, er saa blød, at den let lader sig omrøre med Spatel. En Prøve, hvis Konsistenstal ligger mellem 1000 og 1400, er let at ælte med Haanden. Ligger Konsistenstallet mellem $1400 \mathrm{og}$ 1800, kan Prøven endnu baade æltes og anbringes i Skaalen som en homogen Masse. Mellem 1800 og 2200 er Bearbejdelse ved Haandkraft yderst vanskelig, og Prøven falder let i Stykker, naar den presses ned i Skaalen. Konsistenstal over 1800 er kun fundet ved at forlænge Kurverne, idet Forf. ikke har kunnet ælte saa faste Prøver og derfor først har maattet tilføre dem Vand, inden Forsøget har kunnet foretages.

I de ovenstaaende Grupper fordelte Prøvematerialet af Lillebeltsler sig saaledes, at 3 Prøver var "meget bløde«, 4 var »bløde«, 15 var »nogenlunde faste«, medens Resten (98 Prøver) var »faste« eller »meget faster.

Med Hensyn til Resultaterne fra de Boringer i Lillebeltsleret, der har mest Interesse (Boringerne 1-4 Ø., der betegner Bropillernes Plads) da har samtlige Prøver fra Boring 1 Ø Betegnelsen meget fast, medens Prøverne fra $2 \varnothing$ har Betegnelsen meget fast og fast. Begge

tal paa over 2000, medens Morænelerets i Alssund kun har 1600, saa er der to yderst vigtige Grunde til ikke at lægge disse Tal til Grund for en Sammenligning mellem de to Lerarters Bæreevne. For det forste er nævnte Morænelersprove ikke Middelproven af en Række undersøgte Prøver, men kun en tilfældig udtaget Prove, idet Undersøgelsen af Moræneleret i Alssund forst blev paabegyndt efter Artiklens Fremkomst. (Den senere Undersøgelse viste, at den nævnte Proves Fasthed laa en Del under Gennemsnittets). For det andet har altsaa nu de senere svenske Undersøgelser vist, at man ikke tør sammenligne to saa forskellige Lerarter som Lillebeltsler og Moræneler paa Grundlag af deres Fasthed i æltet Tilstand. Ingeniør Brannov vilde selv i en paatænkt senere Artikel have gjort opmærksom paa, at den omtalte Prove fra Alssund ikke repræsenterede Laget paa tilfredsstillende Maade. Da imidlertid denne Artikel af andre Grunde er opgivet, er nærværende Publication sikkert det bedst egnede Sted for en saadan Berigtigelse. 
disse Boringer har altsaa givet relativt gode Resultater. Derimod har Resultatet af Boring $3 \varnothing$ og særlig af Boring $4 \varnothing$ været mindre tilfredsstillende, idet der i Materialet fra disse Boringer forekommer baade nogenlunde faste og bløde Prøver. Boring $4 \varnothing$ ligger, som det vil ses af Profilet Tavle I, meget nær den i forrige Boreserie udførte Bor. XIII, der ogsaa gav et relativt daarligt Resultat. Det kunde saaledes synes som om man paa dette Sted er stodt paa et Svaghedspunkti Lillebeltsleret. Der bor derfor her vises særlig Agtpaagivenhed ved Funderingen.

Hvad angaar Konsistensen London Clay, da opnaaede 6 af Prøverne Karakteren meget fast og 1 af Prøverne Karakteren meget fastfast. Det skal bemærkes, at den ene Prøve, der med Hensyn til Konsistens er af lidt ringere Kvalitet end de øvrige, er udtaget direkte under Gruslag, hvorfor den har haft særlige Muligheder for Udblødning.

\section{De uæltede Prøvers Konsistens.}

Ovenfor anførte Forsøg med at bestemme henholdsvis Lillebeltslers og London Clays Modstand mod ydre Paavirkning, ganske vist i æltet Tilstand, men ved deres naturlige Vandprocent, gav til Resultat, at begge Lerarterne, naar de optraadte i den for Aflejringen normale Form, befandt sig i Gruppen meget faste Lerarter, en Gruppe indenfor hvilken det ikke var muligt at udskille Nuancer med den her benyttede Fremgangsmaade.

Det er jo imidlertid i de sidste Aar blevet draget i Tvivl, om det er tilladeligt at benytte reltede Prøver som Arbejdsmateriale, selv naar det drejede sig om Sammenligning af hinanden nærstaaende Lerarter, saaledes som de her omhandlede, og Danmarks geologiske Undersøgelse har derfor gjort Skridt til at faa en mere betryggende Undersøgelse i Stand, idet Forfatteren af denne Afhandling fik Lejlighed til at forhandle med den svenske Geotekniker JoHn OLsson om Spørgsmaalet ved et Besøg i Stockholm i indeværende Foraar.

Ifølge Ingeniør OLssox's Raad og under hans Vejledning, for hvilken vi herved bringer ham vor bedste Tak, blev der foretaget Forsøg med Fastheden af uæltede Prøver af begge Lersorter ved Hjælp af en til dette Formaal særlig forarbejdet tungere Kegle (Vægt $1900 \mathrm{gr}$ ), der nu er anskaffet ogsaa af Danmarks geologiske Undersøgelse, og som til praktiske Forsøg med forholdsvis faste Prøver altid vil blive benyttet i Stedet for de tidligere anvendte 100 gr og 60 gr Kegler, der kun kan bruges, naar Leret æltes eller er forholdsvis blødt i uæltet Tilstand. Undersøgelsesmethoden med Anvendelsen af $1900 \mathrm{gr}$-Keglen maa vel anses for at være den, der paa vort nuværende Standpunkt giver de mest praktisk anvendelige Oplysninger om Lerarternes Fasthed i deres oprindelige naturlige 
Aflejringstilstand. Den bestaar ganske simpelt i, at den Prøve, der ønskes undersøgt, uden nogen som helst Forberedelse anbringes paa et solidt Underlag, hvorefter Keglen, der ophænges i en Staaltraad indstilles saaledes, at dens Spids netop berører Lerets Overflade. Derefter udløses Keglen af sin Hvilestilling, og borer sig da et Stykke ned i Leret, Nedsynkningen aflæses og Prøvens Vandprocent bestemmes.

Da Keglens Nedsynkning, som det vil ses af nedenstaaende Forsøgsresultater, er meget ringe, spiller det ingen Rolle, om den ene Prøve er lidt mindre eller større end den anden. Samtlige Prøver ved de her omtalte Forsøg var c. $100 \mathrm{~mm}$ i Diameter og Kegle-Indtrykkene forsvindende i Forhold dertil.

Med Hensyn til Forsøgsresultaterne; der findes angivet paa Skemaet S. 39, skal der gøres opmærksom paa, at Værdierne for »Skärhållfasthet «1 ) kun kan anføres under den Forudsætning, at Prøverne er et fuldgyldigt Udtryk for de Lerlag, de repræsenterer. Saaledes maa det ved Vurderingen af Lerets »Skärhållfasthet« f. Ex. forudsættes, at Lerlaget er frit for Revner og Sprækker, idet saadanne nedsætter dets Bæreevne betydeligt.

Betragter man nu Resultaterne af Undersøgelsen af Lillebeltsleret og London Clay, vil man se, at Maximum for førstnævntes »Skärhållfasthet« ved disse Forsøg er c. 20 t. Forsøget med paagældende Prøve Lillebeltsler forløb i alle Maader tilfredsstillende, og Resultatet er derfor paalideligt. Denne Prøve var forud, saavel af D. S. B. som af D. G. U. betegnet som "meget fast», og dens Vandprocent var ved Forsøget meget nær den samme som den oprindelige (bestemt i Efteraaret 1927). Det samme gælder begge de to andre Prøver af Lillebeltsler, hvoraf den ene, der i Danmark har faaet Betegnelsen »fast« har en »Skärhållfasthet « af $10 \mathrm{t}$ pr. $\mathrm{m}^{2}$, medens den anden der havde Betegnelsen »ret blød « fandtes at have en »Skärhållfasthet« af kun 8 t. pr. m². Da »Skärhållfastheten« for den faste Prøve er mærkværdig lav, bør man senere, naar der bliver Lejlighed til at optage nyt Prøvemateriale ${ }^{2}$ ), gentage Forsøgene for at faa fastslaaet, om Forskellen mellem "meget fast« og »fast《 Lillebeltsler virkelig er saa stor, som disse Forsøg viser.

Med Hensyn til London Clay, da grupperer Resultaterne sig saa smukt omkring »Skärhållfastheten« 25 t. pr. m², at man maa have Lov til

1) Bestemmelsen af Lerprøvernes "Skärhållsfasthet" (for at undgaa eventuelle Misforstaaelser er Ordet ikke oversat til dansk) er foretaget i Stockholm ved Hjælp af den der foreliggende Tabel over Forholdet mellem Keglens Nedsynkning i den uæltede Prove og dennes "Skärhållfasthet".

$\left.{ }^{2}\right)$ Til Trods for, at Proverne opbevares i parafinerede Glas, har de fleste af dem dog i Tidens Lob mistet 1-2\% Vand, hvorfor kun ganske enkelte af Proverne egnede sig til det her omtalte Forsøg, ved hvilket det jo først og fremmest gjaldt om, at Vandindholdet var det oprindelige. 
at antage, at dette Tal er karakteristisk for de her undersøgte Prøver, der igen bestod af meget typisk London Clay. Dette Resultat af Undersøgelsen, at London Clay er noget fastere end Lillebeltsleret, naar begge Lerarter har Betegnelsen »meget fast» og er i Besiddelse af deres naturlige Vandprocenter, stemmer godt overens med Resultaterne fra Forsøgene med det koniske Apparat, idet det fremgaar af Fig. 5a, S. 32, at Skæringspunktet mellem Middelkurven og Linien, der angiver Middelvandprocenten, vil ligge fjernere fra Abscisseaxen for London Clay end for Lillebeltsleret.

\section{Oversigt}

over Forsøgsresultaterne fra Forsøgene foretaget i henholdsvis æltet og uæltet Prøve med henholdsvis 100 gr $30^{\circ}$ Keglen og 1900 gr $60^{\circ}$ Keglen.

\begin{tabular}{|c|c|c|c|c|c|c|c|c|}
\hline $\begin{array}{l}1 . \\
\text { For- } \\
\text { sogs- } \\
\text { Nr. }\end{array}$ & $\begin{array}{c}2 . \\
\text { Prove. } \\
\text { Betegnelse }\end{array}$ & $\begin{array}{l}\text { Vand- } \\
\text { procent }\end{array}$ & $\begin{array}{l}4 . \\
\text { Oprinde- } \\
\text { lig Vand- } \\
\text { procent }\end{array}$ & $\begin{array}{c}5 . \\
100 \text { gr } \\
\text { Keglen } \\
\text { synker } \\
\text { i reltet } \\
\text { Prove }\end{array}$ & $\begin{array}{c}6 . \\
\text { Dertil } \\
\text { svarer } \\
\text { Konsi- } \\
\text { stens- } \\
\text { tallet }\end{array}$ & $\begin{array}{c}7 . \\
1900 \mathrm{gr} \\
\text { Keglen } \\
\text { synker } \\
\text { i ualtet } \\
\text { Prove }\end{array}$ & $\begin{array}{c}8 . \\
\text { Dertil } \\
\text { svarer } \\
\text { Konsi- } \\
\text { stens- } \\
\text { tallet }\end{array}$ & $\begin{array}{l}\text { Omtrentlig } \\
\text { "Skärhall- } \\
\text { fasthet" }\end{array}$ \\
\hline I & $\begin{array}{c}\text { Lillebeltsler } \\
3 \text { Ø. } 6 \\
\text { "fast» }\end{array}$ & 32,7 & 32,9 & $3,0 \mathrm{~mm}=$ & 3156 & \multicolumn{2}{|c|}{$7,0 \mathrm{~mm}=$ c. 4200} & $10 \mathrm{t}$ pr. $\mathrm{m}^{2}$ \\
\hline II & $\begin{array}{l}\text { Lillebeltsler } \\
2 \text { Ø. } 9 \\
\text { "meget fast }\end{array}$ & 30,6 & 30,9 & \multicolumn{2}{|c|}{$1,9 \mathrm{~mm}=7440$} & \multicolumn{2}{|c|}{$4,7 \mathrm{~mm}=$ c. 8000} & $20 \mathrm{t} \mathrm{pr.} \mathrm{m}^{2}$ \\
\hline III & $\begin{array}{l}\text { Lillebeltsler } \\
3 \text { Ø. } 3 \\
\text { ret blødt» }\end{array}$ & 34,1 & 34,1 & \multicolumn{2}{|c|}{$4,0 \mathrm{~mm}=1776$} & \multicolumn{2}{|c|}{$7,2 \mathrm{~mm}=3500$} & $8 \mathrm{t}$ pr. $\mathrm{m}^{2}$ \\
\hline IV & $\begin{array}{l}\text { London Clay } \\
\text { meget fast }\end{array}$ & 21,4 & 21,4 & \multicolumn{2}{|c|}{$1,9 \mathrm{~mm}=7440$} & $\begin{array}{l}3,7 \mathrm{~mm} \\
4,1 \mathrm{~mm}\end{array}=$ & $\begin{array}{l}12960 \\
10380\end{array}$ & c. $25 \mathrm{t}$ pr. $\mathrm{m}^{2}$ \\
\hline $\mathrm{V}$ & do. & 22,0 & 21,4 & \multicolumn{2}{|c|}{$2,3 \mathrm{~mm}=5370$} & $\begin{array}{l}4,1 \mathrm{~mm} \\
4,0 \mathrm{~mm}\end{array}=$ & $\begin{array}{l}10380 \\
10860\end{array}$ & c. $25 \mathrm{t} \mathrm{pr.} \mathrm{m}^{2}$ \\
\hline VI & do. & 22,0 & 22,5 & \multicolumn{2}{|c|}{$2,2 \mathrm{~mm}=5820$} & \multicolumn{2}{|c|}{$4,1 \mathrm{~mm}=10380$} & c. $25 \mathrm{t} \mathrm{pr.} \mathrm{m}^{2}$ \\
\hline
\end{tabular}

En anden og yderst interessant Oplysning har disse Forsøg i Sverige ogsaa givet os:

Ved at betragte Forsøgs-Resultaterne ser man, at der er al mulig Grund til, ogsaa ved de her foreliggende Forsøg, at tage Hensyn til Caldenius' og John Olsson's Advarsel mod at sammenligne Lerarternes Fasthed paa Grundlag af æltede Prøver, thi medens f. Ex. Lillebelts- 
leret i Forsøg I og II ikke er svækket stort ved Altningen (Konsistenstallet i Rubrik 6, der hidrører fra æltet Prøve, ligger meget nær ved Konsistenstallet i Rubrik 8, der hidrører fra uæltet Prøve), saa er Fastheden for London Clay gaaet ned til c. den halve Værdi ved Eltningen (sammenlign Rubrik 6 med Rubrik 8), og en Sammenligning mellem de to Lerarter ud fra æltede Prøver maa derfor i dette Tilfælde medføre en Overvurdering af Lillebeltsleret.

De svenske Undersøgelser over dette Emne, der stemmer med ovenstaaende, viser, at man altid bør benytte en uæltet Prøve og, om det kræves, den tunge Kegle, naar det gælder om at sammenligne to Prøvers relative Fasthed, i Særdeleshed naar det gælder Prøver af forskellige Lerarter. 


\section{London Clays og Lillebeltslerets Plads i den geologiske Tidsinddeling.}

Efter at der i det foregaaende er gjort Rede for saavel London Clays som Lillebeltslerets fysiske Egenskaber i saa stor Udstrækning, som de kan menes at have Værdi ved geotekniske Undersøgelser, skal der her gives en Oversigt over det andet Punkt i Prof. Ussixg's tidligere nævnte Artikel: Overensstemmelsen mellem Lon don Clays og Lillebeltslerets Alder. For at faa et Overblik over dette Spørgsmaal vil vi i det følgende se lidt nærmere paa de to Lerarters Plads i henholdsvis den engelske og den danske geologiske Lagrække.

\section{De tertiære Dannelser i London Bassinet. ${ }^{1}$}

Grænsen mellem det ældste Tertiær i England og det underliggende Skrivekridt er markeret ved et Lag som kaldes "Bull Head Bed, « som væsentlig bestaar af skarpkantet, grønlig, urullet Flint. Over dette kommer Aflejringen "Thanet Sand, " en finkornet, oftest svagt gul, flintholdig Sandart, der indeholder rigelig Kvarts samt store Mængder af Glaukonit. Disse Lag er aflejret i Mellem Paleocæn²) (Thanétien) under den begyndende Transgression af Havet ind over Englands Kyster.

1) Den folgende Beskrivelse af Englands tertiære Dannelser er foretaget paa Grundlag af de engelske Kortbladsbeskrivelser: The Geological Survey of Great Britain. Explanations of sheets, hvortil der henvises. Englands Tertiær findes bl. a. omtalt i Sheet: 238. 256. 257. 267. 270.

Desuden henvises til:

Whitaker. 1889. Geology of London. (Mem. of the Geol. Surv.) Vol. I.

Prestwich, J. 1888. Correlation of Eocene Strata of England, Belgium and France. Quarterly Journal. Geol. Soc. Vol. XLIV.

Woodward, H. B. 1909 \& 1922. The Geology of the London District. Mem. of the Geol. Surv.

$\left.{ }^{2}\right)$ I England benytter man ikke Betegnelsen: Paleocæn, men kalder hele Aflejringsserien fra Thanétien til Yprésien for Eocæn (se Skemaet S. 57). 
Thanet Sandet overlejres af den i petrografisk Henseende ejendommelige Woolwich-Serie, der har to Faciesdannelser: Woolwich Bed, der bestaar dels af marint Sand dels af grønligbrunt Sand, aflejret i Flodmundinger, og Reading Bed, der anses for at være en Ferskvandsdannelse og som bestaar af spraglet (rødt, grønt og gult), stærkt plastisk Ler, der vexler med Sandlag. Dette opfattes som et Tegn paa, at Laget er dannet under en Regressionperiode, hvor Kystlinien var underkastet store Svingninger, men $\operatorname{dog}$ i det store og Hele forskødes udefter. Regressionen var ledsaget af en Temperaturstigning ${ }^{1}$ ).

Woolwich-Reading Serien, der paa Grundlag af sit - ganske vist sparsomme - Indhold af Forsteninger regnes for at være samtidig med Argile plastique i Frankrig og saaledes tilhører $\emptyset_{\mathrm{v} r e}$ Paleocæn (Sparnacien), er rig paa Mineraler, hvoraf Turmalin optræder saa hyppigt, at det af BoswELL ${ }^{2}$ ) betegnes som Ledemineral for disse Lag; desuden findes Magnetit og Zirkon hyppigt, derimod er Glimmer betegnet som sjældent.

Woolwich Serien overlejres af Blackheath-Bed, der bestaar af kvartsholdigt Sand og Grus, ofte sammenkittet til et Konglomerat, rigt paa Forsteninger. Der er i dette Lag fundet 86 forskellige Arter, hvoraf 45 ogsaa findes i den underliggende Woolwich-Serie, 27 kun i Blackheath Bed og 14 saavel i dette Lag som i det overliggende London $\left(\mathrm{Clay}^{3}\right)$. Som Følge af dette Forhold findes der i Faunaen Elementer saavel af Ferskvandsformer som af Delta- og marine Fossiler, og Blackheath Bed repræsenterer saaledes Overgangen mellem den nu tilendebragte Regression og den langvarige Transgression, hvorunder London Clay dannedes.

London Clay, der hører til i Yprésien, Fastlandets Nedre Eocæn, er i sin "normale" Form omtalt saa udførligt i Afhandlingens foregaaende Afsnit (se S. 10), at der her kun skal gives en ganske kort Beskrivelse af dets Egenskaber. London Clay er i Almindelighed ret fedt (der findes dog ogsaa mere sandede Varieteter), selv om det ikke med Hensyn til Finkornethed kommer helt paa Højde med Kontinentets saakaldte plastiske Lerarter (det danske Lillebeltsler, og det franske Argile plastique). Lerarten er blaagraa; ofte findes indlejrede Sandlag, hvilke giver Anledning til de af Teknikere saa frygtede "svage Punkter« i Leret (se S. 11). I London Clay findes talrige septarieformede Konkretioner, der indeholder de ikke særlig hyppige Forsteninger.

1) The Geolygy of the London District. 1922, S. 20.

2) Boswell, P. G. H. 1916. Lower Eocene Deposits of The London Basin. Quart. Journ. Geol. Soc. Vol. lxxi, pt. 3, S. 578.

$\left.{ }^{3}\right)$ The Geology of South London, S. 30. 
Faunaen angiver ikke nogen særlig høj Temperatur, hvorimod Floraen peger henimod et varmere Klima ${ }^{1}$ ).

Forholdene ved Aflejringen af London Clay Laget er blevet sammenlignet med dem, der nu findes ved Ganges' Munding; Laget maa i hvert Fald betragtes som en Deltadannelse paa ret dybt Vand.

Da Forsteninger er ret sjældne i London Clay, har det ikke været muligt at inddele Aflejringen i Underafdelinger. I Lagets øvre Dele er fundet en Del Eksemplarer af Krabbeslægten Xanthopsis (Plagiolophus), der har foraarsaget Sammenstillingen i Henseende til Alder af Lillebeltsler og London Clay.

I London Clay findes et stort Indhold af Pyrit, ligeledes er Selenitkrystaller, Muscovit og Hornblende hyppige.

Jo højere man kommer op i Laget jo hyppigere bliver de før omtalte Sandlag, og alt tyder paa, at Transgressionen er kulmineret under London Clays Dannelse. I det overliggende Lag, Claygate Bed, der tidligere henregnedes til London Clay, men som nu er udskilt som en særskilt Aflejring, tager Sandindholdet nemlig Overhaand,og de sparsomme Forsteninger viser yderligere, at Claygate Bed er aflejret i Saltvand, men under aftagende Havdybder.

Blackheath Bed, London Clay og Claygate Bed henregnes alle tre til Y présien og erstatter i England den franske Aflejring Sable de $\mathrm{Cuise}^{2}$ ), selv om Faunaen i Aflejringerne i de to Lande paa Grund af Faciesforskellighederne ikke er fuldt overensstemmende.

Den med Claygate Laget paabegyndte Regression fortsættes i det overliggende Bagshot Lag, der bestaar af krydslejret, rent Sand, dog med enkelte Lerstriber. Sandet, der er rigt paa Kvarts, Glimmer og Feldspat, men fattigt paa Forsteninger, betegnes som en marin Lavvandsdannelse. Med Bagshot Sandet afsluttes London Bassinets Eocæn, ja hele dets Tertiær, idet den omtalte Regression har bevirket, at denne Del af England under hele den yngre Del af Tertiærtiden har ligget hævet over Havfladen.

\section{Det ældre Tertiær i Danmark. \\ Paleocænet.}

Det danske Paleocæn, saaledes som dette i Almindelighed opfattes, deles i tre Afdelinger: Grønsandet, Kertemindeleret og det kalk-

1) Prestwich, J. 1854: On the distinctive Physical and Palæontological Features of the London clay etc. - Quart. Journ. Vol. X. S. 448.

$\left.{ }^{2}\right)$ se f. Ex. Grgnoux, M. 1926: Géologie stratigraphique. S. 434. 
fri graa Ler. I det store og Hele er denne Inddeling foretaget paa Grundlag af Faciesforskelligheder indenfor Paleocænets Lerarter, f. Ex. disses stærkt vexlende Kalk- og Sandindhold; dog lader de to førstnævnte Lerarter sig ogsaa adskille efter Alder ved Hjælp af deres Fossilindhold. Aldst bliver da ifølge de foretagne Undersøgelser, Grønsandet, der væsentlig bestaar af glaukonitholdigt Sand og graagrøn Mergel. Denne Aflejring forekommer paa Sjælland og paa Samsø, og bl. a. ved Vestre Gasværk har man konstateret Tilstedeværelsen af en righoldig, af $\mathrm{M}_{\mathrm{RCH}}{ }^{1}$ ) og v. KoEneN²) beskreven nedrepaleocæn Fauna.

Grønsandslagets Lerindhold er oftest ringe; Jordartens vigtigste Mineral er Glaukonit, som næppe nogensinde mangler helt, hvorfor Jordarten ofte kaldes Glaukonitkalk eller Glaukonitmergel. Kalkindholdet kan beløbe sig til c. $89 \%$. Kalken findes hyppigt i Form af Foraminiferer; Aflejringen er ofte kvartsrig ${ }^{3}$ ).

Ovenover denne Aflejring har dernæst Kertemindeleret sin Plads i Rækkefølgen. Denne Lerart findes udbredt paa Sjælland, Fyen og i Østjylland; den bestaar af ret fedt, stærkt kalkholdigt, oftest fossilfattigt eller fossilfrit Ler. I Leret findes Diatoméer, Spongienaale og hornstensagtige Lag. Faunaen peger hen imod en noget senere Aflejringstid end Glaukonitsandets ${ }^{4}$ ).

Den tredie Aflejring indenfor det danske Paleocæn, det kalkfri graa Ler, er bl. a. fundet paa Mors og ved Rugaard og regnes i Almindelighed for at være den yngste af Gruppens tre Jordarter, idet Forholdene paa Mors, som jeg senere skal komme tilbage til, menes at tale for en saadan Opfattelse. Da der ikke er fundet Forsteninger i Laget, er det imidlertid vanskeligt at fastslaa dets Alder i Forhold til Gruppens to andre Aflejringer. BøGGILD ${ }^{5}$ ) er da ogsaa mest tilbøjelig til at betragte alle de her omtalte tre Jordarter som Faciesdannelser med indbyrdes ringe Aldersforskel.

\section{Eocænet.}

Til Eocænet henregnes i Almindelighed to af de ejendommeligste danske Jordarter, nemlig Moleret og Lillebeltsleret, idet begge anses for at være dannede i Nedre Eocæn.

1) Мøвсн, O. 1874: Nye Tertiærforsteninger i Danmark. Forhdl. v. 11. skand. Naturforskerm. i Kjøbenhavn 1873.

2) Koenen, A. v. 1885: Ueber eine Paleozäne Fauna von Kopenhagen. Abhdl. d. kgl. Gesellsch. d. Wiss. z. Göttingen. Bd. 32.

3) Bøggild, O. B. 1918: Den vulkanske Aske i Moleret etc. D. G. U. II. Række. 33. S. $130-134$.

$\left.{ }^{4}\right)$ Oversigt o. Danmarks Geologi. 1928. D. G. U. V. R. 4. (J. P. J. Ravn's Afsnit om Tertiæret) S. 68.

$\left.{ }^{5}\right)$ 1. c. S. $126-127$. 
I Moleret, der findes udbredt i det vestlige Limfjordsomraade, har Diatoméerne taget en saadan Overhaand over Lersubstansen, at Jordarten maa betegnes som en lerholdig Diatomékisel. Denne Jordart udmærker sig endvidere ved at indeholde talrige Lag af vulkansk Aske. Medens selve Moleret aldrig er fundet ved Boringer, hvilket dog maaske skyldes dets lidet modstandsdygtige Konsistens, findes de karakteristiske Askelag ofte ved Boringer, ved hvilke de er blevet benyttet som et Hjælpemiddel til at orientere sig i Tertiærets mægtige Lagserie, hvor de forskellige Afdelinger paa Grund af Manglen paa Forsteninger og mange indbyrdes Lighedspunkter i fysisk Henseende kun med stor Vanskelighed lader sig adskille. Foruden disse Askelag indeholder Moleret talrige linseformede Konkretioner af graa, uren Kalksten, saakaldt Cementsten, hvori man finder Aflejringens sparsomme Fauna og Flora velbevaret. Moleret er af Stolt Y $^{1}$ ), Hartz ${ }^{2}$ ) o. fl. henført til Nedre Eocæn.

Lillebeltsleret (det Plastiske Ler) optræder i stærkt forstyrrede Lag i Skrænterne ved Lillebelt og paa Refnæs og er desuden fundet med en Mægtighed af over hundrede Meter, ved talrige Boringer i Jylland og paa Fyen og Samsø. Dets fysiske Egenskaber er saa udførligt beskrevet i det foregaaende Afsnit af denne Afhandling, at jeg ikke her skal komme nærmere ind derpaa. Leret er ofte stærkt farvet, ildrødt eller grønligt, men det kan ogsaa optræde ganske ensfarvet mørkegraat, saaledes som Tilfældet er med Leret i Lillebelts Bund. Kalkholdige og kalkfri Lag vexler tilsyneladende uden nogen Lovmæssighed. Det synes dog at være Reglen, at det røde Ler oftere er kalkholdigt end det graa; men herfra afviger f. Ex. den her omtalte Aflejring i Lillebelt, der til Trods for sin graa Farve er ret stærkt kalkholdig.

Leret er overordentlig fedt og praktisk talt fossilfrit; i de over Hundrede Prøver fra Lillebelts Bund er der saaledes ikke fundet en eneste Forstening. Af Mineraler indeholder det Gips, Baryt og Svovlkis, men ikke, eller kun i ringe Mængde, Glimmer; desuden er der ved Boringer fundet Lag af vulkansk Aske i de nedre Lag af Lillebeltsleret, lige over eller paa Grænsen mellem dette og det underliggende Paleocæn $\left.^{3}\right)$.

Et ganske isoleret Fossilfund ${ }^{4}$ ) (Krabben Plagiolophus Wetherelli)

1) Stolley, E., 1899: Ueber Diluvialgeschiebe des Londonthons i Schleswig-Holstein etc. Arch. f. Anthrop. u. Geol. Schlesw.-Holst. Bd. 3. Kiel u. Leipzig.

$\left.{ }^{2}\right)$ Hartz, N. 1909: Bidrag til Danmarks tertiære og diluviale Flora. D. G. U. II. R. 20. S. 19.

3) BøgGild. 1. c. S. $112-115$.

$\left.{ }^{4}\right)$ Et Par andre Fossilfund (f. Ex. enkelte Stilkled af Pentacriner) er ifl. Ravn (Medd. Dansk geol. Foren. Bd. 2. Hft. 12. S. 26) for daarligt bevarede, til at man ud fra disse tor drage nogen Slutning om Lagets Alder. 
viser, at en Del af Lillebeltsleret er samtidigt med London Clay (Nedre Eocæn), medens Fundet af Avicula limaeformis paa en anden Lokalitet taler for, at i det mindste en Del af Lillebeltsleret er noget yngre, nemlig mellemeocænt ${ }^{1}$ ).

Ovenstaaende er i store Træk den almindelige Inddeling af det ældre danske Tertiær; vi vil nu i det følgende se lidt nærmere paa Berettigelsen af en saadan Inddeling.

At Grønsandsaflejringen hører til i Nedre Paleocæn, bevises fuldt ud gennem Alderen af den rige Fauna bl. a. i Aflejringen ved Vestre Gasværk. Heller ikke er der nogen Grund til at tvivle om, at Kertemindeleret er lidt yngre end Grønsandslaget; thi ogsaa her har man Forsteningerne at holde sig til. Derimod har Bestemmelsen af det kalkfri graa Ler som værende den yngste af de tre Afdelinger, fordi den paa Lokaliteten ved Klitgaard gaar jevnt over i det til Eocæn henførte Moler, kun Værdi, hvis Moleret virkelig hører til Eocænet, thi i det kalkfri graa Ler har man ikke fundet Forsteninger.

Molerets Placering i Nedre Eocæn stammer fra 1899, da dets Alder bestemtes af StoLLEY ${ }^{2}$ ), dels paa Grundlag af Overensstemmelse i Faunaen mellem Moleret og et Par Septarier, som Stoltey havde fundet i Holsten, og som han mente med Sikkerhed at kunne henføre til Nedre Eocæn, da de ligesom London Clay indeholdt Aporrhais Sowerbyi, dels paa Grundlag af Molerets Indhold af Diatoméer og Planterester.

Mod det første Bevis for Molerets nedreeocæne Alder kan der indvendes, at de to Forsteninger af Slægterne Cassidaria og Valvatina, som Moleret har fælles med de løse Septarieblokke i Holsten, ikke er fundet i det faststaaende London Clay, medens paa den anden Side Aporrhais Sowerbyi, som Septarierne har fælles med den engelske Lerart ikke er fundet i Moleret. Moleret og det faststaaende London Clay har med andre Ord ingen sikre nedreeocæne Fossiler fælles.

Da tillige flere andre Spørgsmaal med Hensyn til de omtalte løse Septarieblokke i Holsten (deres Hjemsted m. m.) staar uopklarede hen, maa det faunistiske Grundlag for Molerets Aldersbestemmelse siges at være meget spinkelt.

Hvad angaar det andet Bevis for Molerets nedreeocæne Alder: Overensstemmelsen mellem Molerets og London Clays Indhold af Dia-

1) se herom i "Oversigt o. Danmarks Geologi«, D. G. U. V. R. 4. (J. P. J. Ravn's Afsnit om Tertiæret). S. 71.

2) Stolley, E. 1899: 1. c. 
toméer, da paaviser Stolley, at denne Lighed er meget udpræget, men er dog selv klar over, at Diatoméer ikke er velegnede som Grundlag for en Jordarts Aldersbestemmelse (bl. a. nævner STOLLEY selv, at der ogsaa er stor Lighed mellem Diatoméerne i miocæne og i eocæne Aflejringer). Den nævnte Overensstemmelse mellem Diatoméerne i Moleret og i London Clay vilde derfor ikke være tilstrækkelig til at begrunde Molerets Alder som nedreeocænt, særlig da et Par af de hyppigst forekommende Arter (Coscinodiscus og Triceratium) ogsaa findes i Paleocænet $\left.{ }^{1}\right)$.

Med Hensyn til Molerets Indhold af Planterester, da er dette senere blevet undersøgt af $\mathrm{HARTz}^{2}$ ), der ogsaa kom til det Resultat, at Laget maatte være nedreeocænt, paa Grundlag af Fundet af Cocculites Kanei Heer, en Art som Hartz mener med Sikkerhed at kunne tidsfæste.

Der er imidlertid den Ejendommelighed ved HaRtz's Bestemmelse af Molerets Alder paa Grundlag af Fundet af Cocculites Kanei HeEn, at han først paa S. 16 i nævnte Afhandling, i Beskrivelsen af Arten omtaler, at den findes i de berømte Lag ved Gelinden, som han anser for sikkert paleocæne, men derefter paa S. 19 i samme Afhandling resumerer sin Undersøgelse af Cementstenens Alder med følgende Ord: "Som det vil fremgaa af det følgende, taler ogsaa Cocculites Kanei Heer, den eneste Cementstens-Fanerogam, som er sikkert tidsfæstet, for Cementstenens eocæne Alder, idet denne karakteristiske Plante hidtil kun er kendt fra eocæne Lag. Laget ved Gelinden er sikkert paleocænt ...... Der synes saaledes at være en saadan Uoverensstemmelse til Stede mellem de forskellige Udtalelser, at man maa kræve et mere fyldestgørende Bevis for, at Moleret virkelig er aflejret i Nedre Eocæn (og ikke, som dets Overensstemmelse med Laget ved Gelinden antyder, i Mellem Paleocæn), hvis man som Grundlag vil benytte Cocculites, der af $\mathrm{B} ø \mathrm{GGILD}{ }^{3}$ ) betegnes som "Lagets berømteste Forstening" og af HARTZ $^{2}$ ) benævnes som »en karakteristisk Plante«.

Forklaringen paa Uoverensstemmelsen mellem de forskellige Udtalelser i nævnte Afhandling ligger rimeligvis i, at HARTz snart benytter Betegnelsen »Eocæn« i dens gamle Betydning som omfattende saavel Paleocæn som det nuværende Eocæn (foruden i foran anførte Citat, f. Ex. paa S. 16 Linie 8 f. n. i samme Afhandling, hvor Lagene ved Gelinden kaldes for »de belgiske eocæne, planteførende Lag«), snart i Ordets nu anvendte Betydning som udelukkende gældende Tertiærets næstældste Afsnit (se f. Ex. foran anførte Citat, Afhdl.s S. 16 Linie 15 f. o., hvor

\footnotetext{
1) Stolley, E.: l. c. S. 125.

2) 1. c. S. 19 .

3) 1. c. S. 46 .
} 
Lagene ved Gelinden kaldes Belgiens Paleocæn og S. 19 Linie 17 f. n., hvor London Clay kaldes nedreeocænt).

Hrad nu end Hartz har ment med den vexlende Benyttelse af Betegnelsen Eocæn, saa bortfalder ved den almindelige Indførelse af Betegnelsen Paleocæn enhver Ret til — paa Grundlag af Cocculites Kanei HeER — at betegne Moleret som eocænt; thi Lagene ved Gelinden bliver med stor Enighed af de forskellige Forfattere ${ }^{1}$ ) henregnet til Paleocænet (Mellem Paleocæn - Nedre Landénien - Heersien), og de tertiære Lag paa Hebriderne, som Hartz ogsaa sidestiller med Moleret, tilhører ligeledes Paleocænet, idet de f. Ex. i »The British Isles« (Handbuch d. regionalen Geologie) S. 273 omtales som »not younger than the Thanetian. ${ }^{2}$ )

Den Omstændighed, at Aflejringer med vulkansk Aske er fundet i nær Tilknytning til sikre nedreeocæne Lag (rødt plastisk Ler med Krabben Xanthopsis (Plagiolophus) Wetherelli) saavel ved Hemmoor i Holsten som ved Holmehus i Røgle Klint, kunde maaske synes at tale for Molerets nedreeocæne Alder.

Af det af $\mathrm{GAGEL}^{3}$ ) publicerede Profil fra førstnævnte Lokalitet fremgaar det imidlertid, at de sikre nedreeocæne Forsteninger ikke er fundet indenfor den Del af Profilet, der indeholder de vulkanske Askelag, men i det røde plastiske Ler, der grænser umiddelbart op til dette Lag.

Lerlagene, der findes mellem de vulkanske Askelag, adskiller sig endvidere i petrografisk Henseende en Del fra det røde plastiske Ler, idet de har en ejendommelig blaa Farve og indeholder talrige haarde, sprukne Lerjernstensgeoder med marine Mollusker, Landinsekter og Vedrester $\left.{ }^{4}\right)$.

Hvad angaar Forholdene ved Holmehus i Røgle Klint ${ }^{5}$ ), da svarer de paa flere Punkter meget nær til de ovenfor omtalte Lejringsforhold ved Hemmoor, idet Laget, der indeholder den vulkanske Aske, grænser op til det røde plastiske Ler (Lillebeltsleret), hvori Plagiolophus er

1) Se herom: Kayser, E. 1924: Lehrbuch d. Geologie. Stuttgart. Bd. II. S. 238, 253. Cornet, J. 1923: Geologie. IV. Geologie Stratigraphique. Mons.

Gignoux, M. 1926: Géologie stratigraphique, S. 436 samt

Hartz egne Udtalelser 1. c. S. 16.

$\left.{ }^{2}\right)$ De planteforende Lag paa Hebriderne, hvori bl. a. Cocculites Kanei er fundet, findes indlejrede i Basalt. Hvis Alderbestemmelsen af disse Lag er rigtig, har der altsaa fundet vulkansk Virksomhed Sted i Nordvest-Europa allerede i Mellem Paleocæn, og de Vulkaner, der har bevirket Dannelsen af Askelagene i Moleret, vil derfor ikke være noget isoleret Fænomen, selv om Aflejringen rykkes ned i Mellem Paleocænet.

3) GAGEL, C. 1907: Ueber die untereocänen Tuffschichten und die paleocäne Transgression in Norddeutschland. Jahrb. d. preuss. geol. Landesanst. Bd. XXVIII. Hft. I. S. 154 .

4) BøgGILD, O. B.: 1. c. $83-84$.

5) BøgGild, O. B.: 1, c. S. 74 . 
fundet, og ligesom ved Hemmoor lettes Forestillingen om en Grænse, eventuelt en Overskydning, ved den petrografiske Forskel mellem det røde Lillebeltsler med Plagiolophus og den molerlignende vulkanske Serie ${ }^{1}$ ).

Aflejringerne paa begge Lokaliteter er stærkt forstyrrede. For den danske Lokalitets Vedkommende forklarer V. Nordmann ${ }^{2}$ Lejringsforholdene saaledes, at det Parti af Lillebeltsleret, som staar i Røgle Klint, danner en Slags Randmoræne, opskudt paa en saadan Maade, at de ved Holmehus staaende Lag med vulkansk Aske danner den inderste - og derfor ældste - Kærne, hvorfor Lillebeltsleret, der ligger saavel $\varnothing$. som $V$., herfor maa antages at være yngre end Laget med den vulkanske Aske.

Ifølge ovenstaaende vilde der vel saaledes ikke være noget i Vejen for at antage, at den petrografiske Grænse saavel ved Hemmoor som ved Holmehus tillige paa disse to Lokaliteter danner Grænsen mellem to Aflejringer af forskellig Alder.

Hvis Moleret er aflejret i Mellem Paleocæn, kan det kalkfri graa Ler, der ved Klitgaard underlejrer Moleret, regnes for at være en Faciesdannelse af Nedre Paleocæn ligesom Grønsandsdannelsen og Kertemindeleret, en Anskuelse som ogsaa BøGGILD ${ }^{3}$ ) synes mest tilbøjelig til at nære.

Vi vil nu gaa over til at undersøge, hvilke Holdepunkter vi har for Lillebeltslerets (det Plastiske Lers) Plads i Lagrækken. Oprindelig var man for Aar tilbage tilbøjelig til at henregne alt det plastiske Ler i Danmark til Mellem Oligocænet ${ }^{4}$ ). Senere udskilte $\mathrm{RAvN}^{5}$ ) — paa Grundlag af Fundet af Plagiolophus Wetherelli — det egentlige plastiske Ler, Lillebeltsleret, (herunder ogsaa Leret paa Refnæs) som tilhørende Nedre

1) Paa en Excursion til Hemmoor, foretaget af Deutsch. geol. Ges. (se herom: Monatsber. d. deutsch. Ges. 1909. Bd. 61. S. 430-142), fandt GaGel m. fl. et Transgressionslag liggende paa Kridtets Overflade. Dette Transgressionslag omtaler GAGEı. som paleocænt og bemærker, at det i Sammensætning ganske svarer til det saakaldte Bull Head Bed-Konglomerat, der danner Basis for den engelske mellempaleocxne Aflejring: Thanet Sand. (Se nærv. Afhdl. S. 40). Lejringsforholdene paa Stedet bevirker, at Gagel ikke er i Stand til at udrede dette Konglomerats Forhold til de overliggende Lag. Ifølge ovenfor anforte Grunde for den vulkanske Series paleocæene Alder, har man vel Lov til at forklare Forholdene ved Hemmoor saaledes, at Transgressionslaget ganske simpelt ligger paa sin oprindelige Plads, idet det danner Basalkonglomeratet for den overliggende, nu stærkt forstyrrede, paleocæene vulkanske Serie.

$\left.{ }^{2}\right)$ Se herom: Excursionsberetningen for Excursionen til Vejle-Fredericiaegnen. Medd. Dansk geol. Foren. Bd. 7 (1928).

3) BøgGild, O. B.: l. c. S. 132.

$\left.{ }^{4}\right)$ Ravn, J. P. J. 1897. Nogle Bemærkninger om danske Tertiæraflejringers Alder. (En forelobig Meddelelse). Medd. Dansk geol. Foren. Bd. I. Hft. 4.

$\left.{ }^{5}\right)$ Ravn, J. P. J. 1906. Om det saakaldte plastiske Lers Alder. Medd. Dansk geol. Foren. Bd. 2. Hft. 12. 
Eocæn. Da det øvrige plastiske tertiære Ler: Leret ved Ulstrup, Mariager Fjord osv. stadig henregnes til Mellem Oligocænet, blev det altsaa ved denne Adskillelse nødvendigt at indføre Theorien om en Lakune mellem de to Aflejringer af plastisk Ler her i Danmark. Denne Lakune skulde da repræsentere det Tidsrum, der var forløbet fra Nedre Eocæn til Mellem Oligocæn (Mellem-Øvre Eocæn og Nedre Oligocæn). Samtidigt besluttedes det at indskrænke Benyttelsen af Navnet "Plastisk Ler til udelukkende at gælde det nedreeocæne Ler. Til Trods for, at BøGGLD $^{1}$ ) og sidst i 1924 HARDER $^{2}$ ) har gjort opmærksom paa, at det er en uheldig Sprogbrug, at betegne en enkelt Lerart ved den eneste Egenskab, som er fælles for alle Lerarter, og til Trods for at HARDER desuden har paapeget, at den franske Oversættelse af Navnet (Argile plastique) allerede er benyttet til at betegne en Aflejring i Pariserbassinet, som almindeligt anses for at være ældre end det danske nedreeocæne Ler, hvorved Forvexling let kan opstaa, benyttes Navnet dog stadig i Litteraturen, sidst i "Oversigt over Danmarks Geologi«, hvor man har forsøgt at gøre det til et Egennavn ved at skrive "Plastisk" (med stort Begyndelsesbogstav). Er Navnet uheldigt i geologisk Sprogbrug, saa er det ganske uanvendeligt i geoteknisk, hvor den plastiske Konsistens, der indtræffer for enhver Lerart, naar den indeholder et passende Kvantum Vand, hvert Øjeblik omtales. I denne Afhandling er derfor overalt benyttet det af $\mathrm{HARDER}^{3}$ ) foreslaaede Navn for det eocæne plastiske Ler: „Lillebeltsler«.

I samme Afhandling foreslaar $\mathrm{HARDER}^{4}$ ) endvidere, at Lillebeltsleret paa Grund af dets Samhørighed med London Clay henregnes til $\emptyset_{v}$ re Paleocæn, idet han henviser til, at »man i Frankrig har skudt den nævnte Grænse ${ }^{5}$ ) opad, hvorved London Clay er kommet i Øvre Paleocæn.«

Denne Opfattelse, der blandt franske Geologer fortrinsvis hævdes af $\mathrm{HAUG}^{6}$ ) og hans Elever, bliver imidlertid kraftigt imødegaaet fra anden Side i Frankrig. Bl. a. hævder G. Dubois ${ }^{7}$ ), Professor v. Universitetet i Strasbourg, at hvis man overhovedet skal holde paa en Adskillelse af Paleocæn og Eocæn, (og denne mener Dubors bør opretholdes), saa maa Grænsen mellem disse to Etager ligge mellem Sparnacien og Yprésien (London Clay), thi med Yprésien optræder Nummuliterne for første Gang i Pariserbækkenet, Londonbassinet og »la mer du Nord«,

\footnotetext{
1) BøgGild, O. B.: 1. c. S. 111.

2) Harder, P. 1922. Om Ġrænsen mellem Saltholmskalk og Lellinge Grønsand osv. D. G. U. II R. 38. S. 69.

3) 1. c. S. 69 .

4) 1. c. S. 71 .

$\left.{ }^{5}\right)$ d. e.: Grænsen mellem Paleocæn og Eocæn.

$\left.{ }^{6}\right)$ Haug, Em. 1908 - 1911: Traité de Géologie. II. Les Périodes Géologiques. S. 1418.

7) Ifl. velvillig skriftlig Meddelelse fra Prof. Dubois til Forf.
} 
og denne Begivenhed er saa vigtig, at den bør danne Skel i Inddelingen. Den skarpe Grænse mellem Sparnacien og Yprésien paapeges ogsaa af GIGNOUX ${ }^{1}$ ), hvis Lærebøger i Geologi nu fortrinsvis benyttes ved Undervisningen i Geologi i Frankrig.

Der er saaledes saa velbegrundet Modstand imod at flytte Yprésien (og dermed London Clay) fra Nedre Eocæn til Øvre Paleocæn, at man sikkert bør lade Lond on Clay beholde sin gamle Plads i Nedre Eocæn og rette den danske Inddeling derefter. Samme Plads vil da ogsaa være at tildele den Del af Lillebeltsleret, hvortil Fundet af Plagiolophus Wetherelli maa henføres, thi denne Krabbeart er Ledefossil for Englands Nedre Eocæn. Imidlertid er Krabben Plagiolophus (Xanthopsis) knyttet til den y ngre Del af London Clay, idet den først forekommer højt oppe i Laget, og Lillebeltsleret skulde da være sammenhørende med øvre London Clay. Nu tyder forskellige Forhold imidlertid paa, at man næppe kan opretholde den Opfattelse, at Lillebeltsleret tilhører en enkelt Periode; det er nemlig godtgjort ved Boringer, at det røde Lillebeltsler oftest overlejres af mægtige Lag af mørkegraat Lillebeltsler, og dette maa derfor regnes for at være yngre end øvre London Clay. Fundet af en Avicula, der ifølge RAvN ${ }^{2}$ ) antagelig er identisk med den i det belgiske Bruxellien (Mellem-Eocæn) fundne Aviculoperna $l i$ maeformis VINC., tyder da ogsaa paa, at Aflejringen af det fine Slam, hvoraf Lillebeltsleret er opstaaet, er fortsat i det mindste ind i mellemeocæn Tid.

Med Hensyn til Lillebeltslerets Begrænsning nedadtil i Lagserien, da er denne Grænse markeret meget tydeligt ved de vulkanske Askelag, der som tidligere nævnt ofte i Boringerne er fundne enten i den allernederste Del af Lillebeltsleret eller umiddelbart under dette. Disse Askelag knytter denne ældste Del af Lillebeltsleret, hvori der ikke er fundet Forsteninger, til Moleret i Henseende til Alder, selv om man intet kan sige om, hvilken Del af Moleret, der er samtidig med Lillebeltslerets Basis; (angaaende Fundet af Askelag i Nærheden af det forsteningsførende røde Lillebeltsler i Pøgle Klint henvises til S. 48). Hvis Moleret paa Grundlag af Fundet af Cocculites Kanei HeEr maa henføres til Mellem Paleocæn, er man altsaa berettiget til at antage, at Lillebeltslerets Aflejring er paabegyndt i Slutningen af Mellem-Paleocæn (hvor Dannelsen af de vulkanske Askelag fandt Sted), er fortsat gennem Nedre Eocæn (Laget med Plagiophus Wetherelli) og videre i det mindste til Mellem Eocæn (Laget med Aviculoperna limaeformis).

Manglen paa Transgressionslag mellem Lillebeltsleret og det overliggende Septarieler kunde tyde paa, at de to Aflejringer gaar kontinuer-

1) Gignoux, M. 1926: Géologie stratigraphique. S. 423.

2) Oversigt o. Danmarks Geologi S. 71 . 
ligt over i hinanden. Imidlertid er Septarieleret paa Grundlag af et Par - i Dagforekomsterne fundne - Forsteninger (bl. a. Fusus biformis) henført til Mellem Oligocæn. Der var jo den Mulighed, at Aflejringen af de mere end $50 \mathrm{~m}$ mægtige, forsteningsfri graa Lerlag, der paa flere Steder er fundet umiddelbart ovenover Lillebeltsleret, og som i Almindelighed henregnes til Mellem Oligocæn paa Grund af den petrografiske Lighed med de mellemoligocæne Dagforekomster, var paabegyndt i direkte Fortsættelse af Lillebeltsleret og saaledes dannede den naturlige Overgang mellem denne Lerart og det overliggende paa Grundlag af Forsteninger tidsbestemte Septarieler. At hele Aflejringen af Septarieler hidtil er henregnet til Mellem Oligocæn, skyldes — foruden Fundet af de omtalte Forsteninger — vel ogsaa den petrografiske Overensstemmelse mellem det danske Septarieler og det til Mellem Oligocæn henførte tyske Septarieler, ikke alene i Henseende til Indholdet af Septarier, men ogsaa paa Grund af begge Lerarternes Indhold af Glaukonit og Foraminiferer.

Imidlertid fremgaar det af Beskrivelsen af London Clay (S. 11), at ogsaa denne med Sikkerhed til Nedre Eocæn henførte Lerart er rig paa Septarier og desuden meget glaukonitholdig, hvorfor den nævnte Overensstemmelse i petrografisk Henseende mellem det tyske mellemoligocæne Septarieler og Septarieleret ved Skive lige saa lidt har Betydning for Aldersbestemmelsen af Lerarterne, som den tilsvarende Lighed mellem begge disse Lerarter og det langt æeldre London Clay.

Fundet af planteførende Ferskvandssand fra Nedre Oligocæn ved Moselund (se herom Medd. D. G. F. Bd. 5. Hf. 2. 1917. S. 19) kunde maaske opfattes som et Bevis for, at der indenfor Danmarks Grænser ikke har kunnet finde Aflejring Sted af saa fedt Ler som de her omtalte Lerarter, idet man hidtil har antaget, at disse fede Lerarter var dannede paa meget stor Dybde. RøRDAM ${ }^{1}$ ) drager endog Sammenligning mellem Lillebeltsleret og det røde Dybhavsslam, der i Nutiden dannes paa Verdenshavenes største Dybder. En saadan Antagelse er imidlertid ikke nødvendig. I Reading Bed vexler f. Eks. Lag af det fedest mulige røde Ler uden Overgang med Lag af Sand og Grus, og i Argile plastique findes endog Lag af Brunkul. Disse Forhold forklares ved, at det kolloidale Lerslam, der af Floderne føres ud i Havet, koagulerer i dette, naar Havvandet f. Ex. blot er tilstrækkelig salt. Lillebeltslerets saavel som Septarielerets fuldstændige Mangel paa grovere Bestanddele beviser dog, at Dannelsen af disse Lerarter er foregaaet i det mindste saa langt fra Land, at Aflejringen af Sand og Grus ganske er ophørt, men alene Lerets Kalkholdighed (Calciumionen har samme koagulerende Virkning paa Slammet som Havets Saltindhold) gør det

1) Rørdam, K. 1909: Geologi og Jordbundslære. II. S. 88. 
overflødigt at ty til Antagelsen af unormalt store Havdybder for at forklare Dannelsen af det kolloidale Ler.

Beviserne for Lillebeltslerets kontinuerlige Overgang til Septarieleret er for svage til, at man tør tage det for mere end et Forsøg paa at forklare Fraværelsen af mere grovkornede Jordarter paa Grænsen mellem Lillebeltsleret og Septarieleret. Derimod er det vel — med den her fremsatte Begrundelse - forsvarligt at udvide Perioden for Lillebeltslerets Dannelse til at omfatte Tidsrummet fra Slutningen af Mellem Paleocæn til Mellem Eocæn. I saa Fald vil den paleocæne Del af Leret være afsat samtidig med henholdsvis Argile plastique i Frankrig og Reading Bed i England. Man skal naturligvis ikke lægge for stærk Vægt paa petrografiske Overensstemmelser mellem Lerarter, naar der er Tale om Aldersbestemmelse - den petrografiske Overensstemmelse mellem London Clay og Septarieleret ved Skive, der er af forskellig Alder, er et godt Bevis herpaa - men Ligheden mellem de tre ovenfor nævnte Lerarter er saa udpræget, at det vilde være meget tilfredsstillende, om de paa Grundlaget af Beviser, fremskaffet paa anden Maade, kunde regnes for at være samtidige. Alle de tre Lerarter tilhører nemlig en Extraklasse indenfor de meget svære Jordarter, alle er de i Besiddelse af iøjnefaldende, spraglede, grønne og ildrøde Farver, og i det mindste for Lillebeltslerets og Reading Beds Vedkommende er der endvidere den Overensstemmelse, at Glimmer mangler eller er yderst sjældent i Lagene; (jeg har ikke været i Stand til at faa oplyst, om det samme er Tilfældet med Argile plastique). Hvis derfor Aflejringerne Lillebeltsler, Reading Bed og Argile plastique ad anden Vej kan bevises at være samtidige, berettiges man til at formode, at Dannelsen af disse tre ejendommelige Lerlag ikke skyldes Tilfældigheder, men ganske bestemte Naturforhold, der i Frankrig og England er forsvundet med Udgangen af Øvre Paleocæen, medens de for Danmarks Vedkommende har vedvaret i det mindste til Grænsen mellem Nedre og Mellem Eocæn, hvor Lerartens Farverigdom sandsynligvis forsvinder, medens Manglen paa Indhold af Glimmer og den overordentlige Finkornethed ogsaa kendetegner den efterfølgende Aflejring, det mellemeocæne graa Lillebeltsler. 


\section{Slutning.}

Som omtalt i Indledningen til denne Afhandling blev Undersøgelsen af Lillebeltsleret fra Bunden af Lillebelt og London Clay foretaget af Danmarks geologiske Undersøgelse, for at vi derved kunde blive i Stand til at besvare de tre Spørgsmaal, der var stillet os af De Danske Statsbaner, nemlig:

I. Hvorledes forholder de enkelte Prøver fra Prøveboringerne i Lillebelt sig til hele Laget (Gennemsnitsprøven).

II. Er den i Professor Ussing's Artikel i "Ingeniøren "fremsatte Opfattelse af Lillebeltslerets Konsistens stadig gældende?

III. Staar Lillebeltsleret og London Clay hinanden saa nær i Henseende til fysiske Egenskaber, at man tør overføre Erfaringer med Hensyn til sidstnærntes Bæreevne direkte paa den danske Lerart.

Ovennævnte tre Spørgsmaal suppleredes endvidere af Forfatteren med :

IV. Er Lillebeltsleret og London Clay af samme Alder, saaledes som det bl. a. er nævnt i den af Professor Ussing publicerede Artikel i »Ingeniøren«.

Paa Grundlag af de foretagne Undersøgelser, for hvilke der er gjort Rede i denne Afhandling, mener vi at kunne besvare disse Spørgsmaal paa følgende Maade:

ad. I. Aflejringen af Lillebeltsleret paa Bunden af Lillebelt er i det store og Hele ret homogen, saaledes at Middelprøven for Laget giver et godt Billede af dettes Konsistens. Denne Middelprøve har faaet Betegnelsen : fast, idet Leret ved Prøvens naturlige Vandprocent $(31,9)$ kun vanskeligt lader sig sønderdele med Haanden. Af de undersøgte 120 Prøver af Lillebeltsler har 98 Prøver faaet Karakteren fast eller meget fast, 15 viste sig at være nogenlunde faste, og 7 var bløde eller meget bløde (se Definitionerne af disse Betegnelser S. 36). 
De bløde og meget bløde Prøver stammede fortrinsvis fra Boringer, foretaget umiddelbart udenfor Jyllands Kyst, hvorfor det kunde se ud til, at Lillebeltsleret havde et Svaghedspunkt paa dette Sted.

ad. II. I Professor Ussings Beskrivelse af Lillebeltsleret som værende "en ensformig, overmaade fast, sandfri Lerart, absolut uigennem»trængelig for Vand, men i Modsætning til Morænemerglen til»bøjelig til langsomt at blødes op til en sej Vælling, hvor den ved »Jordoverfladen er i stadig Berøring med Vand, hvorved voldes »de bekendte Skred _ — — - vilde vi foretrække at rette Udtrykket »overmaade fast" til: "gennemgaaende fast» samt Udtrykket absolut uigennemtrængelig til »næsten uigennemtrængelig« (begge Rettelser bør ske paa Grund af de fundne svagere Punkter i Leret). Med Hensyn til Berettigelsen af Sætningen "men i Modsætning til osv." (se ovenfor) da har Lillebeltsleret paa den her omhandlede Lokalitet ikke vist nogen Tendens til at udblødes til en sej Vælling ved Jordoverfladen, hvilket rimeligvis skyldes Saltvandets koagulerende Virkning paa Leret, samt at Lerarten i Lillebelt ikke er udsat for skiftende Udtørring og Opblødning ${ }^{1}$ ).

ad. III. Lillebeltsleret og London Clay tilhører ganske vist begge den »højeste Klasse« indenfor Lerarterne i Henseende til Finkornethed, men ikke desto mindre er Lillebeltsleret en langt federe Lerart end London Clay. Dette viser sig ikke alene gennem Slæmmeresultaterne og Hygroscopicitetstallene for de to Lerarter, men ogsaa ved deres Konsistenskurver og deres naturlige Vandprocenters Beliggenhed.

Man tør derfor ikke direkte overføre Erfaringer med Hensyn til London Clays Bæreevne til ogsaa at gælde Lillebeltslerets, men maa regne med de Aindringer i Lerets Forhold overfor Tryk o. l, der følger af Lillebeltslerets mere plastiske Egenskaber sammenlignet med London Clays.

ad. IV. Den ældste Del af Lillebeltsleret synes at være dannet i Mellem-Øvre Paleocæn og altsaa at være ældre end

1) Man kunde maaske være ængstelig for, at Manglen af opblødt Ler umiddelbart under Bunden af Lillebelt kunde skyldes Strømmens Virkning i Beltet, idet den ikke vilde tillade Ler under en vis Fasthedsgrad at blive staaende i Profilet. Maalinger foretaget henholdsvis i 1883 og 1926 har imidlertid ikke — ifølge Oplysning fra De Danske Statsbaner - vist nogen indbyrdes Afvigelser, hvorfor man vel tør gaa ud fra, at ovenstaaende Ængstelse er ubegrundet, dette saa meget mere, som Fænomenet meget naturligt lader sig forklare alene ud fra de ovenfor i Texten anførte Grunde. 
London Clay, delvis samtidig med de i fysisk Henseende nærstaaende Lerarter: Argile plastique og Reading Bed. Den mellemste Del af Lillebeltsleret er samtidig med London Clay. Endelig er den yngste Del af Lerarten yngre end London Clay, idet Lillebeltslerets Dannelse synes at være afsluttet tidligst i Mellem Eocæn. 


\section{Oversigt over London Bassinets og Danmarks ældre Tertiær.}

\begin{tabular}{|c|c|c|c|c|c|c|}
\hline & & & London Bassinet & \multicolumn{2}{|c|}{ Danmark } & Anmarkninger \\
\hline \multirow{3}{*}{$\begin{array}{l}\text { Oligo- } \\
\text { cæn }\end{array}$} & $\varnothing$ vre & & - & \multicolumn{2}{|l|}{ - } & \\
\hline & Mellem & & $\longrightarrow$ & \multicolumn{2}{|c|}{ (Septarieler) } & \\
\hline & Nedre & & - & \multicolumn{2}{|l|}{$?$} & \\
\hline \multirow{3}{*}{ Eocæn } & Øvre & $\begin{array}{l}\text { Auversien } \\
\text { m. m. }\end{array}$ & \multirow{2}{*}{ Bagshot Bed } & \multicolumn{2}{|l|}{$?$} & $\begin{array}{c}\text { I Hampshire Bassinet: } \\
\text { Barton Clay }\end{array}$ \\
\hline & Mellem & $\begin{array}{l}\text { Lutétien } \\
\text { (Bruxellien } \\
\text { m. m.) }\end{array}$ & & \multicolumn{2}{|c|}{$\begin{array}{c}\text { Øvre Lillebeltsler } \\
\text { (m. Avicula limaeformis) }\end{array}$} & $\begin{array}{l}\text { I Belgien: Sandlag med } \\
\text { Avicula limaeformis }\end{array}$ \\
\hline & Nedre & Yprésien & $\begin{array}{c}\text { Claygate Bed } \\
\text { London Clay } \\
\text { (m. Plagiolophus Wetherelli) } \\
\text { Blackheath Bed }\end{array}$ & \multicolumn{2}{|c|}{$\begin{array}{c}\text { Mellem Lillebeltsler } \\
\text { (m. Plagiolophus Wetherelli) }\end{array}$} & \\
\hline \multirow{3}{*}{$\begin{array}{l}\text { Paleo- } \\
\text { cæn }\end{array}$} & Øvre & $\begin{array}{l}\text { Sparnaci en } \\
\text { (Øvre Landé- } \\
\text { nien) }\end{array}$ & Woolwich \& Reading Beds & \multicolumn{2}{|c|}{ Nedre Lillebeltsler } & I Frankrig: Argile plastique \\
\hline & Mellem & $\begin{array}{l}\text { Thanétien } \\
\text { (Nedre Lan- } \\
\text { dénien } \\
=\text { Heersien) }\end{array}$ & Thanet Sand & $\begin{array}{l}\text { Moler med vulk. } \\
\text { Aske og } \\
\text { Cocculites Kanei }\end{array}$ & $\begin{array}{l}\text { m. vulk. } \\
\text { Aske }\end{array}$ & $\begin{array}{l}\text { I Belgien: Laget v. Gelinden } \\
\text { m. Cocculites Kanei Heer. }\end{array}$ \\
\hline & Nedre & Montien & - & \multicolumn{2}{|c|}{$\begin{array}{l}\text { Det graa Ler } \\
\text { Kertemindeleret } \\
\text { Grønsandsmerglen }\end{array}$} & \\
\hline
\end{tabular}




\section{Summary of the Contents.}

\section{The physical properties of London Clay and Little Belt Clay.}

For many years it has been generally assumed among geologists and engineers that London Clay and the Danish Lower Tertiary Little Belt Clay were the same, both with regard to physical properties and with regard to age (Ypresian). During the past two or three years the decision to build a bridge from the island of Funen to Jutland, having foundations in the aforesaid Little Belt Clay, has brought the question of the similarity of the Danish and the English clays into the foreground; for if they are similar, it would be justifiable to apply to the Little Belt Clay the lessons learned regarding the bearing strength of London Clay, taking due regard to the purely local conditions. This would be of the greatest importance to the work, as it is the first time a big bridge is to be built upon "Plastic Clay" in Denmark.

Investigations were therefore made in Denmark's Geological Survey into the physical properties of London Clay and Little Belt Clay; the sample material for the former ${ }^{1}$ ) consisted of clay from the localities:

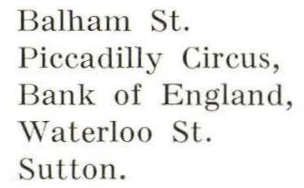

The samples of the Little Belt Clay were all taken from the locality which has given the clay its name.

All the samples of London Clay agreed very well with the descriptions of the clay given in the various English map descriptions; they consisted of dark grey (brownish-grey through oxidation), fairly fine-grained clay, homogeneous, with bright divisional planes. None of the samples contained the septaria referred to in the map descriptions, and as care was taken at the time to secure samples of the most fine-grained London Clay, the samples were also devoid of the bands of sand which occur so frequently.

1) The samples of the London Clay were obtained for this purpose by a Danish State Railways engineer and the author. The samples were cut directly out of diggings and carried to Denmark in paraffined tin boxes to retain their natural moisture. When taking samples from the exposures at Sutton we were most kindly assisted by Stategeologist Mr. H. DEwey of the Geological Survey of Great Britain, to whom we now tender our best thanks. 
All the samples of Little Belt Clay consisted of very fine-grained, homogeneous, dark grey clay, (brownish-grey through oxidation) with bright divisional planes.

An examination of the physical properties of the clay gave the following results:

\section{Size of Particles.}

A combination of AtterberG's and SGHönE's methods was employed in washing the clays, the former being used for particles of $<0.06 \mathrm{~mm}$ in diameter, the latter for particles of greater diameter.

The washing gave the results shown in fig. 1, p. 14 and in the table on p. 15:

The examination shows that Little Belt Clay is considerably finer-grained than London Clay which, however, in comparison with the sample of socalled "greasy" boulder clay shown in the table, must be termed a fine-grained clay. Little Belt Clay gave 92 per cent. clay substance and 8 per cent. of the nearest particle-size group (fine sand), whereas the corresponding figures for London Clay were 43 per cent. and 32 per cent. (the remainder consisted of bigger particles).

\section{Index-number of Hygroscopicity.}

The same proportions between the grade of the two clays is if possible even more clearly shown by the index-number of their hygroscopicity (i. e. the percentage of water at which the clays adapt themselves when allowed to freely absorb moisture in an exicator with vacuum). This index-number was:

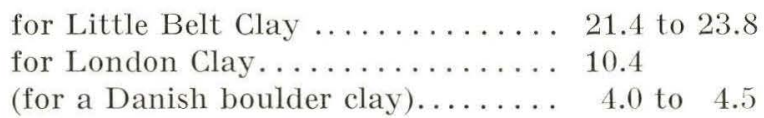

The lower limit for fine-grained clays - arrived at on the basis of the indexnumber of their hygroscopicity - has in accordance with Swedish investigations been put at 10, and it is thus seen that whereas London Clay has just exceeded the limit between very fine-grained and fine-grained clays, the hygroscopicity index-number of Little Belt Clay is so high that only in one other clay, on Java, has a correspondingly high figure (23) been found for its hygroscopicity.

\section{Natural Water Content.}

By the natural water content of a clay is understood the mean water percentage for the clay in its original bed. This water content, which is of course dependent upon both local conditions and upon the nature of the clay, is naturally only of value if the water content of the various samples does not vary too much from the mean percentage.

If the strengths of two clay beds are to be compared with regard to their value as a fundament, it is necessary, however, to know not only their physical properties but also their water content in each particular bed. From the table on p. 20 it appears that Little Belt Clay in the locality in question contains about 31.9 per cent. of water whereas the percentages of the samples of London Clay, taken from places which had been declared satisfactory for building purposes, were very close to the mean figure of 21.1 per cent. 


\section{Consistence.}

An examination of the consistence of clays must necessarily be made in two stages:

1. An examination of the clay itself, regardless of the local conditions; that is to say, showing the changes which take place in the clay when it is artificially given various water percentages, so that it goes through the entire scale of moisture from complete dryness to complete fluid consistence.

2. An examination of the clay at its water percentage in its natural bed in the locality concerned.

The first of these two examinations, which is of interest when it is desired to establish the general physical properties of a clay (its grade, plasticity, etc.), is made either by determining Atterberg's consistence limits in the clay or, more objectively, by drawing the clay's consistence curve, this expressing the resistance of the clay to exterior influence at the various water percentages.

The second examination, which is of most practical importance, is made when it is desired to ascertain the relative natural firmness of the clays, regardless of whether with respect to physical properties they belong to the same group.

\section{Consistence Limits.}

By the consistence limits of clay is understood the water percentages at which a clay passes from one state to another, a distinction being made between :

$$
\begin{aligned}
& \text { the firm state } \\
& \text { the plastic state } \\
& \text { the fluid state. }
\end{aligned}
$$

The boundary between the first two stages is called the lower limit of plasticity and is arrived at as the water percentage at which clay has become so plastic that it can be rolled out into thin threads (the rolling-out limit).

The boundary between the last two stages is called the upper plastic limit and is arrived at as the water percentage at which the clay passes from a plastic to a fluid state (the fluid limit).

For the clays under discussion these limits lay at the water percentages shown in the table p. 25, and it will be seen that the plastic interval (the difference between the upper and lower plastic limits), the so-called index-number of plasticity, is much greater for Little Belt Clay (61.3) than for London Clay (37.0).

\section{Consistence Curves.}

These curves, whose ordinates express the conic weight required by a $60^{\circ}$ cone to sink $10 \mathrm{~mm}$ into kneaded clay when the latter has the water content indicated by the abscisses, are produced by the employment of the so-called Swedish geotechnical apparatus which is figured on p. 27.

The consistence curves alone only illustrate the fineness of the particles of the clay, the curves of the finest-grained clays being farthest to the right, as a fine-grained clay at any consistence binds more water than a sandy clay at the same consistence. Clays containing humus or mica (the latter only being of importance, however, when present in large quantities) are exceptions to this rule, as the presence of these components moves the curve of the particular sample over towards the right. 
Neither Little Belt Clay nor London Clay contain these components, however, and therefore the position of the curves in relation to each other confirms, as do the other investigations referred to above, that the Danish clay is finer in particle than the English, it being further to the right in the coordinate system, and thus at the same consistence binds more water than London Clay (at the consistence 1200 for instance the water percentages are c. 39 and c. 28 see p. 32 ).

\section{Consistence of Clays at their Natural Water Content.}

The conic weight which sinks $10 \mathrm{~mm}$ into kneaded clay at the latter's natural water percentage is called the consistence index-number and is used for judging the firmness of each sample in relation to the normal sample for the bed. It has previously been assumed that the consistence index-number could also be used for judging the relative firmness of different clay beds; but, according to Swedish investigations, the firmness of the various clays is reduced very differently by kneading (the firmness of some clays after kneading falls to onethirtieth of the original; the firmness of other clays in kneaded state is very close to the firmness of the unkneaded sample at the same water percentage, and so on), so that the value of the consistence index-number lies only within the samples of each clay, where, by means of the index-number, it is possible to divide the samples into groups with the descriptions:

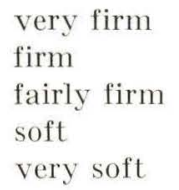

all according to the height of their consistence index-number. Little Belt Clay might on the whole be given the descriptions firm and very firm (consistence index-number 1800 and over); there were, however, also samples of each of the other three groups.

All the samples of London Clay brought home except one might be called very firm (consistence index-number far beyond 2200).

Fig. 5 a. p. 32 gives a summary of curves for the clays. Fig. 5 b. expresses the same, except that there the water percentages are calculated as percentages of the dry matter, according to the Swedish method. Finally, in fig. 6. p. 35 there is summary of the relations between curve and water percentage for:

the greasiest sample of Little Belt Clay.
p poorest
" firmest
softest

As the consistence index-number and the consistence curve are not suitable as a basis for judging the relative firmness of different clays, they being calculated on the consistence of kneaded samples, the system has been adopted in recent years of using the sinking of a heavier cone in unkneaded samples as an aid towards the judging of two different clay beds. The result of applying this method to Little Belt Clay and London Clay is given p. 39.

Experiments II and IV show best how the consistence index-number varies to a different degree with kneading (the consistence index-number of 
the kneaded sample is given in Column 4; the consistence index-number of the same sample in its natural, unkneaded state will be found in Column 6).

The last column shows the resistance to penetration (NB. not resistance to pressure), which illustrates that London Clay in its natural bed is a rather firmer clay than the greasier Little Belt Clay at its natural water content, even in those cases where the samples of both clays are described as "very firm".

\section{The Geological Position of London Glay and Little Belt Clay.}

\section{The Lower Tertiary in the London Basin.}

The boundary between the Lower Tertiary in the London Basin and the underlying Chalk (representing various zones of White Chalk, which indicates severe denudation of the surface in Danian times, of which no deposits exist in England), is marked by the so-called Bull's Head Bed, which for the most part consists of angular, greenish, unrolled flint. Over this lies the Thanet Sand, a fine-grained, mostly slightly yellow, flint-bearing sand, which contains quantities of quartz as well as a great amount of glauconite. This bed has been deposited in Middle Palaeocene (Thanetian) during the progress of the commencing transgression of the sea in over the coasts of England.

The Thanet Sand is overlain by the peculiar Woolwich Serie which, like the corresponding series in France (Argile plastique, Lignites de Soissons) has two facies: 1) the Woolwich Bed itself, consisting of greenish-brown sand deposited at river mouths and often interchanging with gravel deposits, and 2) the Reading Bed, which is considered to be a freshwater deposit and consists of mottled (red, green and yellow) and very plastic clay alternating with sand beds. Everything indicates that this deposit was formed in a period of regression, during which the coast line fluctuated greatly, but on the whole moved outwards. The regression was accompanied by a rise in the temperature.

The Woolwich-Reading Serie, which on account of the fossils in it is reckoned to be contemporaneous with Argile plastique and Lignites de Soisson in France and thus belongs to Upper Palaeocene (Sparnacian), is rich in minerals, of which tourmaline is so abundant that Boswell calls it the distinctive mineral of the Series. Magnetite and zircon are also of frequent occurrence, whereas mica is not mentioned in the list of minerals.

The English Palaeocene deposits come to an end with the Woolwich Serie (Palaeocene and Eocene are not distinguished by English geologists, who have retained the name of Eocene for both Periods), for directly above it is the most important Tertiary English clay - London Clay (Ypresian), the Lower Eocene of the Continent. The lower part of this deposit, which in recent years has been dealt with as a separate layer with the name of Blackheath Bed, consists of quartz-bearing sand and gravel, often cemented into a conglomerate rich in fossils. In this bed 86 different species have been found, and of these 45 are also found in the underlying Woolwich Series, 27 solely in the Blackheath Bed and 14 both in this bed and in the overlying London Clay. As a consequence, there are in the fauna elements of both freshwater forms, estuarine and marine fossils, so that the Blackheath Bed represents the 
transition between the then concluded regression and the long protracted transgression during which the London Clay was deposited.

London Clay is usually greasy (although there are also more sandy varieties), even if with regard to fineness of grain it does not quite equal the so-called plastic clays on the Continent (the Danish Little Belt Clay, Argile plastique); it is a bluey-grey clay, extremely pure, but sand is often interbedded in the clay, this giving rise to the "weak points" so feared by engineers. In London Clay there are numerous septaria-shaped concretions, and these contain the not too abundant fossils.

The fauna does not indicate any particularly high temperature, whereas the flora shows some evidence of a warmer climate.

The conditions under which the London Clay was deposited have been compared with those now at the mouth of the Ganges; the bed may in any case be regarded as a delta deposit in fairly deep water.

It has not been possible to subdivide London Clay. In the upper parts of the layer a number of specimens of the Crab family Xanthopsis (Plagiolophus) have been found, and this has given rise to the comparison of Little Belt Clay with London Clay as regards age.

In London Clay there is also an abundance of pyrites, whilst selenite crystals, muscovite and hornblende are common.

The sand layers already referred to become more frequent towards the top of the clay, and everything indicates that the transgression culminated during the deposition of the London Clay, for in the overlying layer, the Claygate Bed, which was formerly grouped under London Clay but is now placed as a separate deposit, the sand predominates in the layer and the few fossils furthermore show that the Claygate Series was deposited in salt water, but with the sea constantly becoming shallower.

The Blackheath Bed, London Clay and the Claygate Bed are all placed to Ypresian and in England take the place of the French deposit Sable de Cuise, although owing to the differences in the facies, the fauna in the deposits in the two countries do not quite conform.

The overlying Bagshot deposit consists of current-bedded, pure sand, but with a few smears of pipeclay. The sand, which contains abundant quartz, mica and felspar, but few fossils, is described as a marine, shallow water deposit; with Bagshot Sand closes the London Basin's Eocene, in fact the whole of its Tertiaries, the aforementioned regression having had the effect that during the whole of the late part of the Tertiary Period the land has lain above the level of the sea.

\section{The Danish Palaeocene.}

The Danish Palaeocene, as ordinarily regarded, has three phases: Greensand, Kerteminde Clay and the non-calcareous Grey Clay; on the whole this subdivision has been established on the basis of facies-differences in the Palaeocene clays, for instance the very varying lime and sand content in the clays; yet the first two clays are also separable according to age from their fossil content. Thus according to investigations the oldest is the Greensand, which mostly consists of glauconitebearing sand with a basal conglomerate of grey-green marl; this deposit occurs on the islands of Samsö and Sealand, and the presence of a rich Lower Palaeocene fauna, described by Mörch and v. Koenen, has been ascertained particularly at the Western Gas Works at Copenhagen. 
The most abundant mineral in this deposit is glauconite, which hardly ever is wholly missing, for which reason it is most often called Glauconite Limestone or Marl. The lime content can attain up to about 89 per cent. It is often found in the form of Foraminifera; the deposit often has abundant quartz.

Kerteminde Clay comes next above this deposit; this clay is found widespread in Sealand, Funen and East Jutland; it consists of fairly greasy, very calcareous clay, mostly with few fossils and in some places entirely unfossiliferous. It contains Diatoms, Sponge spicules and hornstony beds. The fauna indicates a rather later time of deposition than that of the glauconite sand.

The third deposit in the Danish Palaeocene: the non-calcareous Grey Clay, is usually looked upon as the youngest of the three subdivisions of the group, conditions on the island of Mors seeming to argue in favour of this view; as the deposit has no fossils it is, however, difficult to determine its age in comparison with the other two deposits of the group. As has been stated, the clay is non-calcareous and very finely particled.

\section{The Danish Eocene.}

To Eocene are generally placed two of the most peculiar Danish earths, namely the Mo Clay and the Little Belt Clay, both being regarded as having been deposited in Lower Eocene (Ypresian).

In Mo Clay, which is principally found spread over the western Limfjord area, the Diatoms preponderate to such a degree that the earth may be called an argillaceous diatomaceous silica. This earth is furthermore outstanding in that it contains numerous beds of volcanic tuffs, and whereas the Mo Clay itself has never been found by boring - a circumstance which may however be due to the very slight resistance of its consistence, the characteristic tuffs are often met with in deepborings, where they provide a most welcome means of orientation in the tremendous series of the Tertiary, where the various subdivisions, owing to the lack of fossils and owing to many points of similarity between them in a physical sense, can only be separated with the greatest difficulty.

Apart from these tuffs, Mo Clay contains numerous lenticular concretions of grey, impure limestone, the socalled "cement stone", in which the poor fauna and flora of the deposit are well preserved. Stolley, Hartz and others have placed the deposit to Lower Eocene (Ypresian).

Little Belt Clay (Plastic Clay) occurs in very disturbed beds in the slopes by the Little Belt and on Refsnæs, and has also been found by numerous borings, having a thickness of up to more than hundred metres, in Jutland and on the islands of Funen. The clay is often richly coloured, fiery red or greenish, but also occurs with a single dark-grey colour, as for instance in the bottom of the Little Belt. Calcareous and non-calcareous layers alternate apparently without any definite order; and yet it seems to be the rule that the red clay is more often calcareous than the grey; but there are also exceptions to this, as for instance the deposit in the floor of the Little Belt which, despite its grey colour, is comparatively very calcareous.

The clay is extremely rich and practically unfossiliferous (in the hundred samples from this locality not a single fossil has been found). Of minerals it contains gypsum, baryte and pyrites; volcanic tuffs are also frequently found 
in borings in the lower layer of Little Belt Clay, close to or at the boundary between the latter and the underlying Palaeocene.

And yet the isolated finding of the Crab Plagiolophus Wetherelli points to an age-connection with London Clay, i. e. Lower Eocene, whereas the finding of Avicula limaeformis in another locality argues that at least a part of the Little Belt Clay is somewhat younger, viz. Middle Eocene (Bruxellian).

The foregoing is broadly the general subdivision of Lower Danish Tertiary; we will now go a little more closely into the justification for this subdivision.

The placing of the Greensand deposit to Lower Palaeocene is proved to the hilt by the age of the rich fauna in the deposit at the Western Gas Works; nor is there any reason for doubting the placing of Kerteminde Clay as being slightly younger than the Greensand deposit; for here, too, we have the fossils to guide us. On the other hand, the placing of the non-calcareous Grey Clay to the youngest of the three subdivisions, because in the locality at Klitgaard it passes directly into the Mo Clay placed under Eocene, is only of value if the Mo Clay really belongs to the Eocene, for in the non-calcareous Grey Clay there are no fossils to act as a guide.

The placing of Mo Clay to Lower Eocene (Ypresian) dates from 1899, when it was determined by STOLLEY on the grounds of the similarity as regards Diatoms to London Clay which is regarded as being Lower Eocene (Ypresian). Since then the use of Diatoms as a foundation for determining the age of a deposit has been more and more abandoned, and therefore STOLLEY's determination alone would not be sufficient to establish the age of Mo Clay; Hartz, however, also came to the conclusion that the Mo Clay must be Lower Eocene (Ypresian), as a result of the finding of Cocculites Kanei, a species which in his opinion could be dated with certainty.

There is, however, this peculiarity about the determination of the age of Mo Clay on the basis of the find of Cocculites Kanei, that Hartz first mentions it as belonging to Middle Palaeocene (Thanetian), it being found in the famous beds at Gelinden, which for instance by KAYSER, Cornet a. 0 . is looked upon as an incontestible locality for Palaeocene.

Thus when we see that HARTZ summarises his investigations into the age of the cement stone on the basis of the find of Cocculites Kanei in the following words.

"As will be seen from the following, Cocculites Kanei HEER-the only Phanerogam of the cement stone the age of which has been determined beyond doubt - argues for the Eocene age of the cement stone, as this characteristic plant has hitherto only been known from Eocene. The deposit at Gelinden is undoubtedly Palaeocene........."

there seems to be some discordance between the first and the last part of the sentence, probably owing to the fact that the word "Eocene" has been employed in its old sense, comprising Palaeocene as well as the present Eocene. At any rate Mo Clay-as long as we can only determine its age from Cocculites Kanei HeER after the bipartition of Eocene has been recognised-ought to be placed to Middle Palaeocene (Thanetian).

In this case the non-calcareous Grey Clay which, on the island of Mors, underlies the Mo Clay, may be regarded as being a facies deposit of MiddleLower Palaeocene, i. e. contemporary with Kerteminde Clay and Greensand Marl. 
As regards the position of Little Belt Clay (Plastic Clay) in the series, the find of the Crab Plagiolophus Wetherelli has established that at least a part of the deposit is contemporary with London Clay (Lower Eocene, Ypresian). By the find of Avicula limaeformis the younger part of Little Belt Clay is furthermore established as belonging to Middle Eocene (Bruxellian). But as at the base of the deposit borings have often revealed tuffs which justify one in regarding this part of Little Belt Clay as being contemporary with Mo Clay, and the latter as stated above should be placed to Middle Palaeocene, we must look upon the deposition of Little Belt Clay as having commenced in Middle Palaeocene (Thanetian) and continued through Upper Palaeocene (Sparnacian) and Lower Eocene (Ypresian) and, at the earliest, concluded in Middle Eocene (Bruxellian). This makes the oldest Little Belt Clay (which is oftenest highly coloured) contemporary with Argile plastique in France and Reading Bed in England, and the petrographical agreement between these such peculiar clays thus becomes of still greater interest.

\section{Conclusion.}

The result of the investigations which have been described in the foregoing may be summarised as follows:

It is true that Little Belt Clay and London Clay belong to the same class of clays with regard to physical properties, i. e. the very greasy clays; nevertheless Little Belt Clay is a more fine-grained clay than London Clay. This is shown not only by the washing results and the hygroscopicity index-numbers for the two clays, but also by the situation of their consistence curves and their natural water percentages, from which it would seem as if London Clay is a rather firmer clay in its natural bed than Little Belt Clay (when both clays at the time of taking the samples have been described as vvery firm ().

For the above reasons it is clear that one cannot directly transfer the experience with regard to the bearing strength of London Clay to Little Belt Clay.

The oldest part of Little Belt Clay seems to be older than London Clay, as, on account of the tuffs found, it must be regarded as contemporary with Danish Mo Clay, which again (on the basis of the leaf of Cocculites Kanei HeEr), is placed to Middle Palaeocene (Thanetian), deposited simultaneously with the deposit at Gelinden.

The middle part of Little Belt Clay must - in view of the find of the Crab Plagiolophus Wetherelli-be taken to have been deposited contemporaneously with London Clay in Lower Eocene (Ypresian), and finally, the youngest part of Little Belt Clay must be placed to Middle Eocene (Bruxellian) on account of the find of Avicula limaeformis.

Thus the time of deposition of the oldest Little Belt Clay coincides with the deposition of Argile plastique in France and Reading Bed in England, with which two clays it is, from a petrographical point of view, closely connected. The cause of the simultaneous deposition of three such uniform, peculiar clays may thus possibly be a common factor characteristic of the geographic or climatic conditions of that period. 

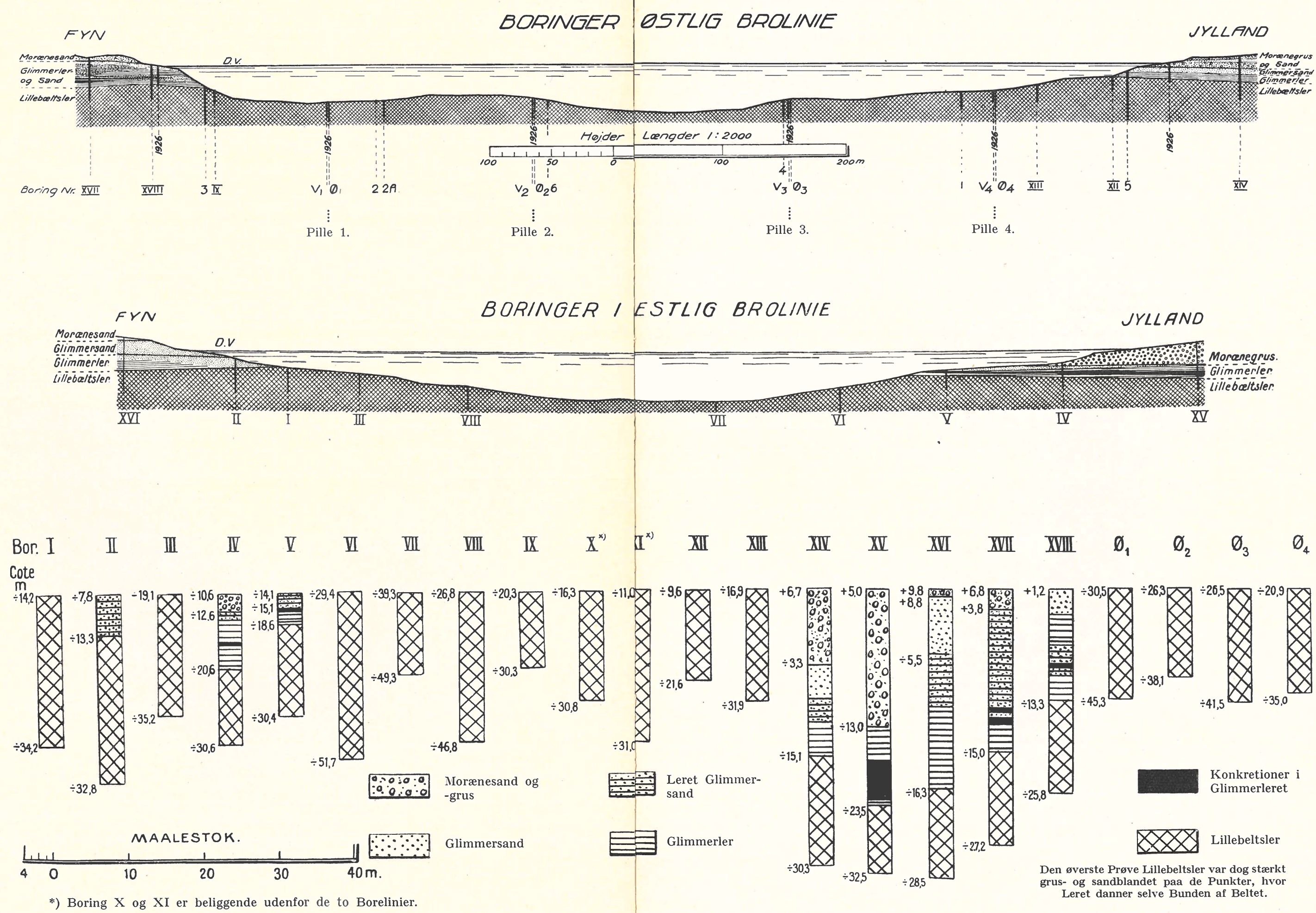